\title{
Hasankeyf Şehabiye Medresesi (Sultan Süleyman Külliyesi)
}

\author{
Abdüsselam ULUÇAM \\ Prof. Dr., Karabük Üniversitesi, Edebiyat Fakültesi, Arkeoloji Bölümü, Karabük, Türkiye, \\ aulucam@karabuk.edu.tr (Sorumlu Yazar/Corresponding Author)
}

\begin{tabular}{|c|c|}
\hline Makale Bilgileri & ÖZ \\
\hline $\begin{array}{l}\text { Makale Geçmişi } \\
\text { Geliş: } 01.09 .2020 \\
\text { Kabul: } 30.09 .2020 \\
\text { Yayın: } 25.12 .2020 \\
\text { Anahtar Kelimeler: } \\
\text { Mimarlık Tarihi, } \\
\text { Hasankeyf Vekâyinamesi, } \\
\text { Şehabiye Medresesi, } \\
\text { Külliye, } \\
\text { Cas. }\end{array}$ & $\begin{array}{l}\text { Ilısu Barajı suları altında kalan Hasankeyf'in önemli anıtlarından birisi Sultan Süleyman Külliyesi } \\
\text { olarak tanınmaktadır. Ancak külliye Melikü'l Adil Şehabeddin Gazi tarafından 750-753/1351-1354 } \\
\text { y1lları arasında yaptırılmıştır. Üç tarafı revak ve öğrenci odalarıyla çevrilen bir avlu ile güneyindeki } \\
\text { derslikler, müderris odaları ve mescit bölümlerinden oluşmaktadır. Mescidin batısına, küçük ölçekli } \\
\text { kapalı bir avlu eklenerek bitişiğindeki metruk bir Artuklu medresesine geçiş sağlanmıştır. Mimaride } \\
\text { yöresel harç malzemesi cas (alçı) ile tutturulmuş moloz taş kullanılmıstır. Avlunun güneyindeki } \\
\text { eyvanın iki yanında yer alan büyük odalardan birisi buraya defnedilen Şehabeddin Gazi ile veba } \\
\text { salgınında ölen üç oğlu; diğeri ise Sultan Süleyman için türbe haline getirilmiştir. Sultan Süleyman, } \\
\text { 809-818/1406-1416 yılları arasında medresenin doğu cephesini yenileyerek muntazam kesme taş } \\
\text { malzemeden yapılmış minare, taçkapı ve çeşme ile birlikte medreseye anıtsal bir görünüşe } \\
\text { kazandırmıştır. Bunlar üzerinde yer alan kitabelerdeki tarih ve bâni adlarında bazı çelişkiler } \\
\text { mevcuttur. Şehabiye Medresesi'nin mihrapları ve kapalı avlunun kubbesi ile Sultan Süleyman'ın } \\
\text { eklediği mimari unsurlar Yeni Hasankeyf'teki Külttür Park'a taşınmıştır. Diğer kısımları sular altında } \\
\text { kalmıştır. Şehabiye Medresesi, Hasankeyf'teki kültür varlıkları arasında tarihi ve kimliği bilinen } \\
\text { Eyyûbiler döneminin önemli bir eseridir. }\end{array}$ \\
\hline
\end{tabular}

Hasankeyf Sahabiye Madrasah (The Suleymaniye Islamic Complex)

\begin{tabular}{|c|c|}
\hline Article Info & ABSTRACT \\
\hline Article History & $\begin{array}{l}\text { he Suleymaniye Complex is considered to be one of the important monuments of Hasankeyf now } \\
\text { en submerged under the waters of the Ilisu Dam. The Complex was built between the years of } 750\end{array}$ \\
\hline $\begin{array}{l}\text { Received: } 01.09 .2020 \\
\text { Accepted: } 30.09 .2020 \\
\text { Published: } 25.12 .2020\end{array}$ & $\begin{array}{l}753 / 1351-1354 \text { by Melikü'l Adil Şehabeddin Gazi. It consists of an atrium surrounded by porticos and } \\
\text { students' rooms on three sides, as well as classrooms, mudarris rooms and prayer rooms in the south. } \\
\text { By adding a small-scale closed atrium to the west side of the prayer room, passing into a derelict }\end{array}$ \\
\hline $\begin{array}{l}\text { Keywords: } \\
\text { Architecture History, } \\
\text { Hasankeyf Chronicle, } \\
\text { Sahabiye Madrasah, } \\
\text { Külliye (The Islamic } \\
\text { Complex), } \\
\text { Cas mortar. }\end{array}$ & $\begin{array}{l}\text { Artuqid madrasah adjacent to the prayer room was ensured. Rubble stone bonded by regional mortar } \\
\text { called cas (plaster) was used in the architecture. One of the large rooms located on both sides of the } \\
\text { Iwan in the south of the atrium was turned into a turbeh (small mausoleum) for Şehabeddin Gazi, who } \\
\text { was buried here, and his three sons who died from the Plague; the other one, for Suleiman the } \\
\text { Magnificent. Renovating the east front of the madrasah between the years of } 1406 \text { and } 1416 \text {, Suleiman } \\
\text { the Magnificent contributed to the madrasah gaining a monumental appearance with minaret, crown } \\
\text { door and fountain made of uniformly cut ashlar stones. There is incoherence regarding the dates and } \\
\text { names of the founders on the inscriptions above these. Sahabiye Madrasah's mihrabs and the dome of } \\
\text { the closed atrium, as well as the architectural components included by Suleiman the Magnificent were } \\
\text { transported to the new Hasankeyf Culture Park. Other parts are left underwater. Sahabiye Madrasah is } \\
\text { a significant monument of the Ayyubid period with a well-known history and culture among the } \\
\text { cultural properties in Hasankeyf. }\end{array}$ \\
\hline
\end{tabular}

Atıf/Citation: Uluçam, Abdüsselam. "Hasankeyf Şehabiye Medresesi (Sultan Süleyman Külliyesi)". Selçuklu Medeniyeti Araştırmaları Dergisi (SEMA) 5 (Aralık 2020), 37-58. https://doi.org/10.47702/sematr.2020.3

"This article is licensed under a Creative Commons Attribution-NonCommercial 4.0 International License (CC BY-NC 4.0)" 


\section{GíRiș}

Ilısu Barajı'nın suları altında kalan Hasankeyf' in Aşağı şehir merkezinde "Sultan Süleyman Külliyesi" adıyla bilinen önemli bir manzume yer alıyordu. Bu yap1 grubunun bir kısmı Yeni Hasankeyf yakınındaki Kültür Parka taşınmış, büyük bir bölümü ise daha kazı çalışmaları tamamlanamadan baraj suları altında kalmıştır.

Yapıların doğusundaki anıtsal cepheden yükselen minare, taçkapı ve çeşmedeki kitabelere göre tanımlanan bu manzumenin Eyyûbi hükümdarı Emir Süleyman tarafindan yaptırıldığı tescillenmiş ve literatüre de bu şekilde geçmiştir. Ancak külliye daha ayrıntılı olarak gözden geçirildiğinde tamamının bu tarihte yapılmadığı, Emir Süleyman'ın mevcut yapılarda bazı tadilatlar gerçekleştirdiği, doğu cephesini de eklettiği anlaşılmaktadır. Nitekim aynı hükümdar Er-Rızk Camii'nin kuzey cephesindeki taçkapı ile minareyi ve iç kale yolu üzerindeki Orta Kapıyı da inşa ettirtmiştir.

Bu durumda "Sultan Süleyman" ya da "Süleyman Han Külliyesi" olarak bilinen manzumenin asıl elemanlarının daha önce yapıldığı ortaya çıkmaktadır. Görsel olarak ilk defa Gertrude Bell'in 1911 tarihinde fotoğrafladığ ${ }^{1}$ külliye, Hasankeyf'te bilimsel araştırma yapan Albert Gabriel tarafindan 1940’ta yayınlanan kitabında etraflıca tanıtılmıştır. ${ }^{2}$ Ayrıca, Hasankeyf Vekâyinâmesi ${ }^{3}$ olarak bilinen kronik tarih yazmasında da ayrıntılı bilgiler mevcuttur. Bu yapılar, Hasankeyf'in kültür tarihi üzerinde yapılan birçok bilimsel çalışmada da yer almıştır. ${ }^{4}$ Hasankeyf'in "Örenyeri" sıfatıyla 1. derece arkeolojik sit alanı olarak tescil edilmesinden sonra ${ }^{5}$ kültür varlıkları arkeolojik kazılarla gün yüzüne çıkarılmaya başlanmıştır. ${ }^{6}$ Aşağı Şehirde ${ }^{1967}$ 'de gerçekleştirilen yeniden yerleşim faciasının ortasında kalan dini ve sosyal içerikli tarihi yapıların araştırılmasına öncelik verilmiş ve çalışmalar

\footnotetext{
${ }^{1}$ Gertrude Bell, "www.gerty.ncl.ac.uk" (Erişim 7 Temmuz 2020).

${ }^{2}$ Albert Gabriel, Voyages Archaelogique Dans la Turque Oriantale (Paris: E. de Boccard, 1940), 64-66.

3 İbnu'l Emir İbrâhîm el Munşî el-Hısnî (v.822/1420) tarafından Arapça olarak kaleme alınan ve özgün adı Nuzhetu'n Nâzir ve Râhatu'l Hâtir olan yazma eser Viyana Milli (Kraliyet) Kütüphanesi'nde bulunmaktadır. Eyyûbiler tarihi, özellikle Hasankeyf Eyyûbileri konu edildiğinden, araştırmacılar kitabın tercüme ve tanıtımında Hasankeyf Vekâyinamesi adını vermişlerdir. C. Cahen'in keşfettiği eser Eyyüp Tanrıverdi ve Yusuf Balüken tarafından tercüme edilerek yayınlanmıştır (Yusuf Balüken, Târîhu Hısn-ı Keyfâ, (Tahkîk ve'd Dirâse, Te'lif: El Hasan bin İbrahîm el-Münşî el-Hısnî, Arabca) İstanbul: Nûbihar Pak Ajans Yayıncıl1k, 2019). Vekâyiname, müellifin hitabıyla Eyyûbi hükümdarı 'Sultan el-Meliku'l-Âdil Ebu'l-Mefâhir Fahru'd-dünyâ ve'd-dîn Süleymân" zamanında yazıldığı halde, bu tarihler ve sonraki olaylara yer verilmeden bitirilmiştir. Özgün nüsha, önlü arkalı tek numara verilmiş 110 varaktan (220 sayfa) oluşmaktadır. Tercüme baskılarda kitap formatına göre sayfa numaraları değişmektedir. Aktarılan bilgilerin çoğu çağdaşı ve önceki itibar edilir temel tarih kaynaklarına dayandırıldığından, çoğu seyahatnamelerdeki kişisel görüş ve yorumlardan çok bilimsel bir metotla yazılmış, Eyyûbilerin Hasankeyf kolu hakkında eksik ve karanlıkta kalan birçok konu bu eserle aydınlığa kavuşmuştur.

${ }^{4} \mathrm{Bu}$ konuda bk. Ömür Bakırer, Onüç ve Ondördüncü Yüzyıllarda Anadolu Mihrablarl (Ankara: Türk Tarih Kurumu, 1976), 221-222, 234; Burhan Zengin, Hasankeyf Tarihi ve Tarihi Eserleri (İstanbul: 2001), 149-159, 197; Ali Kılc1, "Hasankeyf Vakıf Eserleri”, V. Vakıf Haftası (Restorasyon ve Vakıfların Ekonomik ve Sosyal Etkileri Semineri) (Ankara: VGM Yayınları, 1987), 159-192; Hüseyin Yurttaş, Hasankeyf Yapılarının Sanat Tarihimizdeki Yeri (Erzurum: Atatürk Üniversitesi, Sosyal Bilimler Enstitüsü, Doktora Tezi, 1991),108-113; Hüseyin Yurttaş, "Hasankeyf’te Artuklu, Eyyûbi, Akkoyunlu ve Osmanlı Dönemi Mimari Eserleri”, Türkler, ed. Hasan Celal Güzel (Ankara: Yeni Türkiye Yay. 2002), 8/170-172; Ali Miynat, Bir Ortaçağ Kenti: Hasankeyf (Muğla: Muğla Üniversitesi, Sosyal Bilimler Enstitüsü, Yüksek Lisans Tezi, 2008), 168-169.

${ }^{5}$ Hasankeyf Kültür ve Tabiat Varlıkları Diyarbakır Bölge Kurulu tarafından 1981 tarihinde tescil edilmiştir.

${ }^{6}$ Mardin Müze Müdürlüğü başkanlığında, M. Oluş Arık tarafından 1986'da başlanan kazılar, Ilısu Barajı kapsamında 1991 yılında GAP Bölge İdaresi Başkanlı̆̆ı'nca desteklenen "Hasankeyf Tarihi ve Arkeolojik Sit Alanı Araştırma, Kazı ve Kurtarma Projesi” adıyla BK Kararlı kazıya dönüşmüş, 2004 yılından itibaren de tarafımızca sürdürülmüştür. Kazı, Koruma ve Onarım çalışmalarıyla ilgili yayınlar kaynakçada verilmiştir.
} 
şehir merkezinde yoğunlaştırılmıştır. ${ }^{7}$ Belli başlı yapılar arasında Sultan Süleyman Camisi ve müştemilatı da yer almaktadır (Resim 1-3).

\section{Tanımlama}

M. O. Arık hocadan sonra tarafimızca da sınırlı alanda yapılan kazılarda ortaya çıkan kalıntılarla kaynaklardaki çizim ve fotoğraflar göz önünde tutulduğunda, Sultan Süleyman Camisi olarak bilinen yapıların birbirleriyle bağlantılı üç bölümden oluştuğu görülmektedir:

\section{Eski Medrese Bölümü}

Kompleksin batı bölümünün büyük bir kısmı yol ve mevcut evlerin altında bulunduğundan kazısı tamamlanamamıştır. Ancak ortaya çıkarıldığı kadarıyla, revaklı bir avlu etrafında öğrenci odaları ile güneyde enine dikdörtgen planlı bir mescidin bulunduğu (Çizim: 2); mimaride düzgün kesme taş malzeme kullanıldığı, doğu duvarında ikinci bir kata veya dama (?) çıkılan bir merdivenin yer aldığ 1 tespit edilmiştir. Plan, mimari üslûp ve revaklı avlusundaki dikdörtgen havuzu ile döşeme taşlarının düzgün ve mermer kalitesinde oluşu, Artuklu döneminde Hasankeyf, Mardin ve Diyarbakır'da örnekleri görülen çağdaşı medreselerden biri olma ihtimalini çağrıştırmaktadır. Medresenin düzgün yapı taşları 1967 ve sonrasında yeni yerleşim sırasında sökülerek evlerin inşaatında kullanıldığından mimari detayları büyük ölçüde kaybolmuştur (Resim: 4).

\section{Mescit, Medrese ve Türbeler Bölümü (Şehabiye Medresesi)}

Yapılar grubunun ana unsurunu doğudaki kompleks oluşturmaktadır. Anıtsal doğu cephesi ile medrese, mescit ve türbelerden oluşan bu bölümün de kuzeyinde kare planlı, üç yanı revaklarla çevrili büyük bir avlu yer almaktadır (Resim 5). Ancak kuzey revakı ile bağlı olduğu medrese hücreleri yol ve şahıs evlerinin altında kalmış; doğu revakı ve ardındaki odaları ise daha önceden yıkılmış veya doğudaki cephe ve müştemilatı yapılırken ortadan kaldırılmış olmalıdır. Kalıntıları kazılar sırasında ortaya çıkarılmıştır (Resim 6-7). Diğer revaklarla öğrenci hücreleri kısmen günümüze ulaşabilmiştir. Avlunun ortasında dikdörtgen planda tasarlanmış büyük bir havuz mevcuttur.

Avlunun güneyinde, orta aks üzerinde büyük bir eyvan ile kapalı derslikler ve müderris odaları bulunmaktadır (Resim 8). En önde, kıble cihetinde enine dikdörtgen planlı tek sahından oluşan bir mescit yer almaktadır. Ortadaki eyvandan bir kapıyla geçilen ve üzeri sivri beşik tonozla örtülen harim içten kalın cas (alçı) harcı ile sıvanmıştır. Tonoz bingisi altında tüm mekânı kuşatan bir yazı kuşağı görülmektedir. Ancak yazılar okunamayacak derecede tahrip olmuştur. Bu kuşak üzerindeki üzengilere yaslanan tonoz kemer yaylarının duvarla bitişen kısımlarında da Kûfi harf karakterli kitabe izleri yer almaktadır (Resim 9-10). Diğer mekânlara geçişi sağlayan açıklıkların kesme taşla çatılmış yüksek sivri kemer yayları ve etraflarındaki çerçeveler kabartma palmet ve mukarnas dizileriyle süslenmiştir (Resim: 11). Kıble duvarında kesme taşla yapılmış bir mihrap mevcuttur. Mukarnas kavsaralı derin nişi, iki kademeli kuşatma kemerleri ve dış kuşaklardaki basit geometrik ve bitki tezyinatı ile dikkat çekmektedir. ${ }^{8}$ (Resim: 12$)$.

Mescidin batısında yüksek sivri kemerli bir açıklıkla geçilen kare planlı, üzeri tromp geçişli kubbe ile örtülmüş büyük bir mekân yer almaktadır. Kazılar sırasında kıble duvarında bir mihrap

\footnotetext{
71966 yılında Hasankeyf'i ziyarete gelen dönemin Cumhurbaşkanı'nın, o günlerde çoğu mağara konutlarda yaşayan Hasankeyflilerin "daha iyi koşullarda yaşayabileceği yeni bir yerleşim alanı oluşturulması” talimatını vermesi üzerine, projeyi hazırlayıp uygulayanlar tarafından merkezdeki birkaç anıtsal yapı dışında tarihi kentten kalan kültür varlıklarının tamamı 1967'de dozerlerle yıkılarak yerlerine gecekondu türünden yeni evler yapılmıştır.

8 Bk. Bakırer, Onüç ve Ondördüncü Yüzyllarda Anadolu Mihrablarl, 327-328; Şekil: 74,75; Resim: 167,168; Yurttaş, “Hasankeyf’ te Artuklu, Eyyûbi, Akkoyunlu ve Osmanlı Dönemi Mimari Eserleri”, 8/171.
} 
nişinin alt yapısı ortaya çıkarılmıştır. Mescidin devamı şeklinde tasarlanmış olabileceği düşünülen bu mekâna kapalı avlunun güney eyvanından yine yüksek sivri kemerli bir açıklıkla geçilmektedir.

Avlu ile mescit arasındaki medrese odaları daha sonra türbelere dönüştürülmüştür. Eyvanın batısındaki oda Şehabeddin Gazi ve kardeşleri, doğusundaki oda ise oğlu Emir Süleyman ve çocukları için seçilmiştir. Türbeler mevcut medrese odalarının mimari yapısı üzerine yüksek kasnak ve kubbe eklenmesiyle oluşturulmuştur (Resim:13-14). Kubbe içlerinde cas malzemeyle şekillendirilmiş tezyinat unsurları mevcutsa da kapalı avlu kubbesindeki kadar özenli değildir. Türbelerdeki mezarlara ait taş, alçı veya ahşap malzemeden yapılmış sanduka kalıntıları günümüze ulaşabilmiştir (Resim:1516). Mezarların çoğunun daha öncelerde açılarak tahrip edildiği anlaşılmaktadır.

$\mathrm{Bu}$ bölümün (Şehabiye Medresesi’nin) en görkemli mimari unsuru olan doğu cephesinde, kuzeydoğu köşede minare; bitişiğinde taçkap1 ve avlunun güneydoğu köşesine yerleştirilen kastal (çeşme) yer almaktadır (Resim: 17). Her üç eleman da düzgün işlenmiş kaliteli Hallan (Urfa) taşından yapılmış, mimari tasarımları kadar estetik form ve bezemelerine özen gösterilmiştir.

Kare kaide üzerinden yükselen silindirik gövdeli minarenin şerefesi ile petek kısmı yıkılmıştır. Minarenin kaide ve gövdesi değişik motif ve yazılarla tezyin edilmiştir. Süsleme kompozisyonu açısından kaide pabuç altında bir çift yatay kaval silme kuşakla ikiye; gövde pabuç üstünden itibaren dört ana bölümde ele alınmıştır. Kaidedeki yatay silme çerçeveler arasında geometrik süsleme kuşağı, pabucun dört yüzünde kare panolar içine Ma'kîlî (satrançlı Kûfi) hatla yazılmış "Kelime-i Tevhid" yer almaktadır. Pabuçtaki kuşatma kemeri alınlıklarında iri madalyonlar içinde kıvrık dal, palmet ve rûmîlerden oluşan bitki motifleri mevcuttur. Kaidenin her yüzüne üçer adet kare panolar oluşturan ma'kîlî yazı ve geometrik geçme motifleri işlenmiştir. Doğu yüzüne yapım kitabesi yazılmıştır. Gövdenin birinci bölümünde dört ana yönde sivri kemerli kaval silmelerden oluşan panolar içinde bitki kompozisyonlu bezemeler görülmektedir. İkinci bölümde palmet dizileriyle dolgulanmış kuşağın üstünde kaval silmelerden meydana gelen 6 yüzeysel kemer yer almaktadır. Üçüncü bölümde her biri farklı kompozisyona sahip 8 adet geometrik süsleme panosu bulunmaktadır. Dördüncü bölüm ise düşey doğrultuda sıralanıp üstte küçük kemerlerle nihayetlenen kaval silmeler, araları damla motifleriyle bezenmiştir. Yıkılan şerefe altlığından günümüze bir sıra mukarnas dizisi gelebilmiştir (Resim: 18).

Minare kaidesine bitiştirilen taçkapı anıtsal bir görünüşe sahiptir. Selçuklu döneminin eyvan türü taçkapıları tarzında tasarlanmıştır. Dış cephesi içten sekiler üzerinden yükselen sütuncelere yaslanmış kuşatma kemeri ve en dışta mukarnas dizisi bulunan geniş süsleme kuşakları ile çerçevelenmiştir. Kuşaklarda geometrik motifler yer almaktadır. Düz atkı taşlı kapı açıklı̆ı üzerindeki kemer alınlığında üç sıra halinde kitabeler mevcuttur. Kapının kuşatma kemeri üstündeki kısmı yıkılmıştır (Resim: 19).

Sultan Süleyman Türbesi bitişiğinde görkemli bir çeşme yer almaktadır. Kitabesinde "Kastal" şeklinde belirtilen bu eser de muntazam kesme taş malzemeyle yapılmıştır. Form olarak yine Selçuklu döneminin mukarnas kavsaralı taçkapılarına benzemektedir. Cepheden dışa taşırılan çeşmenin nişi, içte sütuncelere yaslanan kuşatma kemerinin çevrelediği mukarnaslı kavsara ile taçlandırılmıştır. En dışta kademeli silme kuşaklardan oluşan dikdörtgen bir çerçeve yer almaktadır. Kavsaranın hemen altıda avluya bakan bir açıklık mevcuttur. Üstünde kitabe yer almaktadır (Resim: 20-21). Bir bölümü tahrip edilmiş olan niş duvarı, çeşme Kültür Park'a taşınmadan önce onarılmıştır.

\section{Kapalı Avlu Bölümü̈}

Üçüncü bölüm aslında ana yapı (Şehabiye Medresesi) ile birlikte tasarlanmış, diğer bölümlere geçişi sağlayan küçük bir "kapalı avlu" niteliğindedir. Orta mekânı kubbe ile örtülü, farklı büyüklükte 
üç eyvanlı bu bölüm, ana avlu, mescit ve eski medrese arasında yer almaktadır. Kubbe içten mukarnas dolgulu alçıdan (cas) zarif motiflerle tezyin edilmiştir (Resim: 22-23). Kapalı avlunun kuzey eyvanından Şehabiye Medresesi'nin batı revakına; batı eyvanından eski medresenin mescidine, güney eyvanından da Şehabiye Medresesi'nin mescidine bitişik kare mekâna geçilmektedir. Ayrıca avlunun kuzeybatı köşesinden, açılan bir koridordan eski medreseye geçiş sağlanmıştır. Güney eyvanı kıble yönündeki taş mihrabı ile aynı zamanda son cemaat yeri işlevini de görmüş olmalıdır. Eyvan duvarı boyunca yükselen ve Zengî üslûbunda iki renkli taşlarla örülen mihrap nişinin kavsarası bitki motifli mukarnaslarla, dış çerçeve ise bir sıra palmet dizisiyle bezenmiştir (Resim: 24).

\section{Tarihçe}

Külliyenin yapımı ile ilgili dört adet kitabe bulunmaktadır. ${ }^{9}$ Ancak kitabelerde yer alan yapım tarihleri ve bâni isimleri ile yaşadıkları yıllar arasında bazı tutarsızlıklar görünmektedir. İlk kaynak olarak karşımıza çıkan Hasankeyf Vekâyinâmesi'ne göre Medrese (yani Külliye), Hasankeyf Eyyûbi hükümdarı Emir Melikü'l Adil Şehabeddin Gazi tarafından yaptırılmıştır. ${ }^{10}$ Eyyûbi hükümdarlarını konu alan kaynakların çoğunda Şehabeddin Gazi'nin kitap okumayı çok sevdiği, ilim adamlarına değer verip kendilerinden azami derecede faydalandığı ve çoğu zaman medreselerde okutulan derslere devam ettiği yer almaktadır. Dönemin Şafii fikhı âlimlerden Şeyh Nizameddin El Acemî’nin Hasankeyf'i ziyaretinden son derece memnun olmuş, uzun süre yanında tutarak ilminden ve sohbetlerinden faydalanmış, O'nun için bir de medrese yaptırmaya karar vermiştir. ${ }^{11}$ Hükümdar, medresenin yapımı için Hacı Abdullah b. Mâverdi'yi görevlendirmiş ve inşaata 750/1350 yılında başlanarak 754/1354'te dört yılda tamamlanmıştır. ${ }^{12}$

Medresenin mimarisinde ilk değişiklik, yapının banisi Şehabeddin Gazi’nin 768/1366-1367 yılında ölümü üzerine, eyvanın batısındaki kapalı dersliğe defnedilmesi ${ }^{13}$ ve buranın türbeye

\footnotetext{
${ }^{9}$ Bk. Gabriel, Voyages Archaelogique Dans la Turque Oriantale, 67; Kılc1, "Hasankeyf Vakıf Eserleri", 192; Yurttaş, Hasankeyf Yapılarının Sanat Tarihimizdeki Yeri, 108-113; Yurttaş, "Hasankeyf”te Artuklu, Eyyûbi, Akkoyunlu ve Osmanlı Dönemi Mimari Eserleri”, 105; Miynat, Bir Ortaçă̆ Kenti: Hasankeyf, 168.

10 "Bu yıl 750 (1350) sultan, Allah rızası, sevap ve ecir amacıyla ilim tahsil edecek talebeler için makamın doğusunda Şihâbiyye Medresesi'nin yapılmasını emretti. Medresenin yapım işine nezaret etmek üzere Hacı Abdullâh b. el-Mâverdî'yi görevlendirdi. Hacı Abdullâh onun özel naibi idi. Vezirlik yetkilerine sahipti.” (Vekâyinâme, 78b, 124). 754/1353-1354 y1lı girdi. Sultan el-Meliku'l-Âdil, Hısnkeyfâ'da idi. .. Bu yıl makamın doğusunda yapılmakta olan Şihâbiyye Medresesi tamamlandı. Daha önce ifade ettiğimiz üzere sultan, 750/1349-1350 yılında bu medresenin yapılmasını emretmişti. Sultan daha sonra sergilerin serilmesini, kandillerin asılmasını emretti. Kendisi de kaleden inerek medresenin binasını inceledi. Buraya Şeyh Alâaddîn b. el-Hatîb'i beș vakit namaz için imam olarak tayin etti. Medreseye güzel vakıflar bağladı. Buna vakıf olmak üzere bir han yapılmasını emretti. Bu han dahi bir yıl sonra tamamlandı ve medresenin vakıflarına eklendi. $\mathrm{Bu}$ han ise İbn Sabîh Camii yakınındadır." denilmektedir. (Vekâyinâme, 87a).

11 "Hısnıkeyfa'ya değerli âlim Şeyh Nizâmeddîn el-Acemî gelmişti. Şeyh Nizâmeddîn büyük bir imam idi. Sultan ona büyük bir itibar gösterdi. Onu yanında tuttu. Eğitim öğretim işleri makamına onu tayin etti. $\mathrm{Bu}$ işlerinin sorumluluğunu ona verdi. Kendisi de onun yanında okudu, ondan fikıh ve nahiv tahsil etti. Ayrıca Kadı Necmeddîn b. Kadı Hasan, Şeyh Alâaddîn b. Şeyh Muhammed el-Hatîb ve kardeşi el-Hatî̉b Hasan da onun yanında okudular. Kendisinin Ahkâm ve kadâyâ adlı eseri vardır. Allah ruhunu kutlu, mezarını nurlu eylesin." (Vekâyinâme, 100b; Miynat, Bir Ortaçağ Kenti: Hasankeyf, 112.

${ }_{12}$ Avluya girilen taçkapı üzerindeki kitabede $752 / 1351$ yılında Gazi b. Muhammed tarafindan yaptırıldığı yazılıdır. Kitabe A. Gabriel tarafindan okunmuş (Voyages Archaelogique Dans la Turque Oriantale, 67); Kılc1, "Hasankeyf Vakıf Eserleri”, 192; Besim Darkot, "Hısn Keyfa", İslam Ansiklopedisi (İstanbul: MEB Yayınları, 1977), 5/453; Bakırer, Onụ̧̈ ve Ondördüncü Yüzyllarda Anadolu Mihrablart, 221; Yurttaş, Hasankeyf Yapılarınin Sanat Tarihimizdeki Yeri, 95-96. Gazi b. Muhammed tarafindan yenilendiği belirtilmektedir (Yurttaş, "Hasankeyf’te Artuklu, Eyyûbi, Akkoyunlu ve Osmanlı Dönemi Mimari Eserleri”, 105.)

13“768/1366-1367 yılında .. Sultan .. su toplama (siroz?) hastalığına yakalanmıștı. İnsanların arasına çıkmaz oldu. Hekimler onu muayene ve tedavi ettiler. Ancak sancıları artmaya devam etti. Artık yanına kimse sokulmuyordu. ... Saltanatı oğlu el-Meliku'l-Eşref'e verdi. Tarih 768 rebiülahirin sekizi (12 Aralık 1366) idi. $\mathrm{Bu}$ sırada hastalığı ağırlaştı. Sancıları arttı. Mardin'e gitti. Hastalığı son derece şiddetlendi. Hekimler muayene
} 
dönüştürülmesiyle başlamıştır. 775/1373-1374 y1lında tüm bölge ile birlikte Hasankeyf'te de etkin olan veba salgınında ölen Eyyûbi hükümdarı Emir Eşref ve kardeşleri de babaları Şehabeddin Gazi'nin yanına, eyvanın batısındaki mekâna defnedilmişlerdir. ${ }^{14}$

Veba salgınındaki toplu ölümler nedeniyle Hasankeyf'te hayatın durma noktasına gelmesi ve sosyal içerikli yapıların çoğunun mezarlığa dönüşmesi ${ }^{15}$ nedenleriyle uzun süre bu külliye de metruk kalmış olmalıdır. Şehabeddin Gazi'den sonra hükümdar olan oğulları Melikü'l Eşref ((768-775 / 1367 1374) ile Sultan Melikü's Salih unvanını alan Seyfeddin Ebubekir (775-778 / 1374-1376) zamanlarında, bölgede baş gösteren kıtlık, Karakoyunluların tahakkümü ve iç çekişmeler yüzünden ${ }^{16}$ Hasankeyf' te önemli bir varlık gösterilememiştir.

Sultan Süleyman döneminde (780-827/1378-1424) şehirde yeniden canlanmalar görülmüş, sosyal hayatla birlikte kent mimarisinde de birtakım düzenlemelere gidilmiştir. Hükümdarın imar faaliyetleri arasında babasının yaptırdığı Şehabiye Medresesi de yer almaktadır. 809-818/1406-1417 tarihleri arasında yapının kuzeydoğu köşesine bir minare ile avlunun doğusuna taçkapı ve çeşmenin yer aldığı anıtsal bir duvar inşa ettirmiştir. Kaidesindeki kitabede minarenin 809 (1406) tarihinde Şehabeddin Gazi tarafından yaptırıldığı yazılı ise $\mathrm{de}^{17}$, bu tarihte Sultan Süleyman hükümdar olup Şehabeddin Gazi bundan 39 yıl önce vefat etmiştir. Çeşmenin kitabesinde ise Türkçe anlamı ile: "Allah'ın yardımına muhtaç, hizmetkâr, Eyyûbi Muhammed'in oğlu, Gazi'nin oğlu Süleyman, Allah onların encamını hayreylesin. Yücelerin yücesinin aşkına ve cennetteki kasırlarının ümidiyle... niyaz ederek, bu çeşmenin bina edilmesini emretti. Allah hayırl kılsın, Zilhicce 818/Şubat 1416" yazılıdır. Minare kaidesinin güney yüzündeki 859 (1455) tarihli El Melik Kâmil II. Ahmed'e ait kitabenin ise okuyucuya nasihat vermeye yönelik hadisleri içerdiği, yapımla ilgisi olmadığı anlaşılmaktadır. ${ }^{18}$

yaptılar, tabipler tedavi uyguladılar. Ancak hastalığı gittikçe daha da ağırlaşıyordu. Mardin hükümdarı elMeliku'l-Mansûr kendisini ziyaret etti. Bu şekilde 768 Cumadelulanın yirmi yedinci gününe kadar (29 Ocak 1367 Cuma) Mardin'de kaldı. Bu tarihte Allah’ın rahmetine göç etti. .. Sonra Şihabiye Medresesi’ne taşındı. Bu medreseyi kendisi hayatta iken inşa etmişti. Kendisi bu medreseye defnedildi naaşı onun taşına gömüldü." Vekâyinâme, 99b-100a.

${ }^{14}$ Orta çağda meydana gelen veba salgınları, kentleri ve üzerinde yaşayan insanları savaşlar kadar etkilemiştir. 775/1373-1374 yılında Diyarbakır bölgesinde baş gösteren veba salgını Mardin'de başlayıp Hasankeyf'e sıçramış, oradan da tüm bölgeye yayılmıştır. Gün geçtikçe etkisini artıran salgın, kimi günler Hasankeyf’te kırktan fazla kişinin ölümüne sebebiyet vermiştir. Halkın yanı sıra Eyyûbi ailesine de sirayet etmiş, önce hükümdarın kardeşleri Melik Umman ve Melik Ömer, daha sonra bizzat hükümdar vebaya yakalanarak vefat etmişlerdir. Onlar, Şehabiyye Medresesi’nde babalarının yanına defnedilmişlerdir. Vekâyinâme, 107a -107b, 166-167; Miynat, Bir Ortaçă̆ Kenti: Hasankeyf, 120.

15 Arkeolojik kazılar sırasında cami, medrese ve zaviye gibi vakıf kayıtlı çoğu yapıların avlu ve büyük mekânlarında yoğun mezarlarla karşılaşılmıştır. Sur dışında bulunan Emir Şemseddin Ahmed bin Sabih Camisi ile bitişiğindeki Şehabiye Medresesi'ne vakfedilmek üzere yaptırılan (Vekâyinâme, 34b, 87a) hanın tamamında muhtemelen vebadan ölenler için kireçle doldurulmuş çok sayıda mezar ortaya çıkarılmıştır. (Bk. Abdüsselam Uluçam, Hasankeyf Projesi 2008-2009 Çalışmaları, (2010), 24-25, 39, 75-76, Resim: 32-34, 39. Kazı raporunda, bu mekânın henüz Emir Şemseddin Ahmed Camisi olduğu bilinmediği için "Mardinike Külliyesi II. Blok Yapıları" olarak tanımlanmıştır.

${ }^{16}$ Vekâyinâme, 107b -110b; Miynat, Bir Ortaçă̆ Kenti: Hasankeyf, 121.

${ }^{17}$ Minare kaidesinde, “Bu mübarek minarenin yapılmasını Allah'ın aşkı ile onun her şeyi saran inayetine nail olabilmek için, Allah hayırlı kılsın, kudretli Yaradan'ın yardımına muhtaç fakir kul Eyyûbi Turanşah oğlu, Abdullah oğlu, Ebu Bekir oğlu Gazi emretti. Allah onun hâkimiyetini daim kılsın, sene 809/1406" (Yurttaş, Hasankeyf Yapılarının Sanat Tarihimizdeki Yeri, 109). Türkçe anlamında Arapça bir kitabe yer almaktadır. Ancak minare, Sultan Süleyman tarafından Er-Rızk Camii minaresinin de ustaları olan Muhammed ve Osman adlı iki kardeşe yaptırılmış olmalıdır. Kitabedeki aidiyet çelişkisi, yazıyı taşa hakkeden ustanın kendisine verilen metni eksik işlemesinden, ya da Emir Süleyman'ın babasına hürmeten böyle yazdırtmış olmasından kaynaklanmalıdır.

18 Yurttaş, Hasankeyf Yapılarının Sanat Tarihimizdeki Yeri, 113; Yurttaş, "Hasankeyf'te Artuklu, Eyyûbi, Akkoyunlu ve Osmanlı Dönemi Mimari Eserleri”, 171. 


\section{Gözlem ve Değerlendirme}

Şehabiye Medresesi'nin kurulum şemasına bakıldığında, bir bütün olarak tasarlandığı kanaatini vermektedir. Ancak inşaatta kullanılan malzeme ve işçilikle birlikte değerlendirildiğinde, batıdaki medrese bölümünün daha özenli, mimari elemanların düşey doğrultudaki görüntüsünün daha düzgün olduğu dikkati çekmektedir. Bölgedeki benzer yapılar arasına konulduğunda ise Artuklu üslûbu ve yapı geleneğine işaret etmektedir.

Şehabiye Medresesi'nin yapımında zemin döşemeleri, kapı-pencere çerçeveleri ve kemerlerde düzgün kesme taş, diğer mimari unsurlarda yöreye özgü "cas" harciyla tutturulmuş moloz taş kullanılmıştır. Teknik analizler sonucunda yüksek kemerleri oluşturan taşların dışarıdan getirildiği, diğerlerinin yöreye ait kireç taşı ocaklarından kesildiği anlaşılmıştır. İklimin çok sıcak olması nedeniyle, Hasankeyf’teki tüm yapılarda olduğu gibi duvarlar oldukça kalın tutulmuş, çoğu tonoz olan örtü sisteminde duvar içlerinde hava akımı sağlanabilecek şekilde galeriler oluşturulmuştur (Resim: 1, 8). İç yüzeyler castan mâmul harçla sıvanmış, mimari süslemelerin tamamında yine değişik oranlarda katkı maddeleriyle seyreltilmiş cas kullanılmıştır.

Şehabiye Medresesi yapılırken, inşaatın batısındaki metruk Artuklu (?) medresesi de elden geçirilerek kullanılmış olmalıdır. İki medrese arasındaki bağlantıyı ve geçişi sağlayan kapalı avlu niteliğindeki mekânın tasarlanması yanında, bu medreseye geçilmek üzere avlunun güneybatısında ayrıca bir koridor oluşturulması, iki medresenin birlikte kullanıldığını göstermektedir. Şehabiye Medresesi'ne sonradan eklenen avlu taçkapısındaki kitabede "752 (1351) yılında Gazi b. Muhammed tarafından yenilendi" ibaresi ${ }^{19}$ de buna işaret etmek için yazılmış olmalıdır.

Şehabiye Medresesi avlusunun kuzey ve doğu kanatlarındaki mimari doku hakkında somut bir veriye ulaşılamamıştır. Tasarımında olduğu varsayılan avlunun kuzeyindeki revak ile medresenin giriş bölümü ve iki yanındaki medrese odaları mevcut yol ve evlerin altında kalmış, baraj bitimine kadar da boşaltılmadıklarından arkeolojik kazıları yapılamamıştır. Doğu kanadındaki revak ve hücreler ise ya daha önceden yıkılmış ya da Emir Süleyman'ın ekleri yapılırken kaldırılmış olmalıdır. Buraya sonradan eklenen minare, taçkapı ve çeşme ile doğu duvarı, avluyu çeviren doğu revakının yerine yapılmış görünmektedir. Kazılar sırasında mevcut duvarın dışında, bu kanattaki medrese hücrelerinin temelleri ortaya çıkartılmıştır (Çizim:2). Her ne kadar minarenin bitişiğindeki taçkapıdan avluya geçilebilmekte ise de özgününde bu taçkapının kuzeyde olduğu düşünülmektedir.

Medresenin güneyinde, revak yerine orta aks üzerinde büyük bir eyvan ile iki yanında kapalı büyük mekânlar tercih edilmiştir. Ancak günümüze ulaştığı şekliyle simetrik bir düzenleme görülmemektedir. Eyvanın batısında yer alan iki odaya karşılık doğuda tek mekân bulunmaktadır. Kazılar sonunda ortaya çıkan plan şeması göz önünde tutulduğunda ise mescitte mihrabın kıble duvarının ortasında olmadığı; doğu duvarının da yıkılmış olduğu görülmektedir. Bu durumda aslında mescidin doğuya doğru devam ettiği; kuzeyinde bir büyük odanın daha yer aldığı anlaşılmaktadır. Mescidin doğusunda, Sultan Süleyman Türbesinin dış duvarı hizasında bu odaya karşı gelecek şekilde yüksek kemerli bir açıklığın bulunuşu da bu durumu teyit etmektedir. Her ne kadar A. Gabriel'in çiziminde minare kaidesi dışarıda kalmak üzere doğu cephesi bir bütün olarak gösterilmiş ise de minarenin medrese avlusunun kuzey doğu köşesindeki revakın üzerine oturtulduğu anlaşılmaktadır. Böylece medresenin avluyu üç yönden saran revak ve medrese hücreleri ile genel aks üzerinde simetrik, dengeli bir düzenlemeye sahip olduğu anlaşılmaktadır.

Mimaride kullanılan malzemelerle inşaat tekniği ve alçı süslemeli kubbeler göz önünde tutulduğunda, eyvanın batısındaki Gazi ve vebadan ölen oğullarına ait türbenin hemen değil, Emir

\footnotetext{
${ }^{19}$ Yurttaş, "Hasankeyf’te Artuklu, Eyyûbi, Akkoyunlu ve Osmanlı Dönemi Mimari Eserleri”, 171.
} 
(Sultan) Süleyman'ın kendisi için yaptırdığ türbe ile birlikte ekleme ve tadilatlar sırasında yapıldığ1 daha akla yakın görünmektedir. Çünkü Şehabeddin Gazi vefat ettiği sırada (768/1367) medresede eğitim öğretim devam ediyordu.

Minarenin pabuç ve bazı yazı içerikleri dışındaki form ve süslemeleri, iki yıl sonra aynı ustalar tarafından yapılan Er-Rızk Camisi (811/1409) minaresinde de tekrar edilmiştir.

Yapının doğu cephesinde yer alan çeşme, tasarımı ve cepheden dışa taşırılmış mimari görünüşü ile dikkati çeken farklı bir özelliğe sahiptir. Selçuklu hanlarındaki taçkapı formlarını hatırlatan yapının ortasında kapı olmayan, yüksekte kalmış bir açıklık mevcuttur. Geleneksel çeşme formlarında görülmeyen bu ayrıntı, yapının aynı zamanda bir sebil olarak da kullanılması için tasarlandığını akla getirmektedir. Sivri kuşatma kemer kilit taşına kadar yükselen kavsaranın mukarnas süslemelerindeki derinlik de Niğde Alâeddin Camisi'nin doğu taçkapısı gibi 1şık gölge dönüşümleriyle farklı siluetler oluşturabilecek mistik bir perspektif sergilemektedir.

En öndeki mescit kısmına eyvandan açılan bir kapıdan geçilmektedir. Ancak bu kapı eyvanın ortasına değil, doğu duvarına daha yakın bir konumdadır. Artuklu geleneğinde tasarlanan enine dikdörtgen planlı tek sahından oluşan mescit boydan boya sivri beşik tonozla örtülmüştür. Bu örtüde de hafifletme ve hava sirkülasyon kanalları mevcuttur. Medresenin kıbleye bakan güney duvarında mescitte, batısındaki mekânda ve medreseye geçiş bölümü eyvanında olmak üzere üç adet mihrap yer almaktadır. Bölgede birçok cami/mescitte mezheplere tahsisen üç mihrap geleneği yaygındır. Kapalı avlunun güney eyvanı aynı zamanda son cemaat yeri işlevini de yerine getirmiş olmalıdır.

Türbeleri oluşturan mekânların duvarları kubbe kasnaklarıyla birlikte yükseltilerek kitlesel görünüşe hareketlilik kazandırılmıştır. Kasnaklarda açılan basit düzenekli galerilerle hem örtü sisteminin ağırlığı hafifletilmiş hem de hava sirkülasyonu ile klima etkisi sağlanmıştır. Dıştan taşla kaplanıp üzerine killi toprak dökülen kubbeler, içten istiridye yivli tromplara veya iri mukarnas hücrelerinden oluşan alçı süslemeli pandantiflere oturtulmuştur. Ayrıca çoğu tahrip olmuş kitabe kuşakları ve bitki motifli bezemelere yer verilmiştir. Türbelerde Eyyûbi hanedanına mensup emir ve yakınlarına ait çok sayıda mezar ve sanduka bulunmaktadır. Hemen hepsi tahrip edilmiş olan sandukalar taş, alçı veya ahşap malzemeyle şekillendirilmiştir (Resim: 15-16). Çoğunda nesih-sülüs hatlarla yazılmış Besmele ile başlayan Ayetü'l Kürsi veya Mülk Suresi'nin ilk ayetlerine yer verilmiştir. Türbelerin taşınması sırasında, kalan sanduka parçaları ile bazı iskeletler Batman Müze Müdürlüğ̈’’nce müzeye nakledilmiştir.

Hasankeyf'te mimari ve sembolik anlam açısından en görkemli iki minareden birisi Şehabiye Medresesi'ne aittir.

Osmanlı dönemi Tapu Tahrir Defterleri ve Vakıf kayıtlarında, Hasankeyf'te "Adiliyye Zaviyesi" adıyla bir vakıf eseri kaydı vardır. ${ }^{20}$ Eyyûbilerin Hasankeyf Emiri Şehabeddin Gazi "Adil" unvanı ile maruf bir hükümdardır. Yaptırdığı eserin adının kendi döneminde medrese, işlev açısından ise zaviye olduğu; eğitim öğretimin hayratını bitiştirdiği (kitabede geçtiği şekliyle "yenilediğì") eski medresede sürdürüldüğü düşünülebilir. Ya da buradaki hükümdar mezarlarının bulunduğu hücrelerin türbeye dönüştürülmesi sonucu, gelen ziyaretçilerin çoğalması, veba salgını sonrasında medrese tedrisatının yapılamaması gibi nedenlerle vakfiyesi ve vakıf gelirleri devam eden külliyenin "Adiliyye Zaviyesi" olarak Osmanlı kayıtlarına geçmiş olması da muhtemeldir. Çünkü Hasankeyf Eyyûbi hükümdarı Emir Melikü'l Adil Şehabeddin Gazi'nin han ve hamam gibi vakfa gelir sağlamak amacıyla yaptırdığı binalar dışında bilinen bir hayratı bulunmamaktadır. Oğlu Emir Süleyman'ın da

\footnotetext{
${ }^{20}$ Bk. "Evkāf-i Kazā-i Hısn-i Keyf, der-Vilāyet-i Diyār-i Bekr", 998 Numaralı Muhâsebe-i Vilâyet-i Diyâr-i Bekr ve Arab ve Zü'l-Kâdiriyye Defteri (937/1530) 1/261-266, Ankara: 1998.
} 
"El-Melikü’l Adil Ebu'l Mefâhir Süleyman” șeklinde “Adil” unvanıyla anılması ve uzun saltanat y1llarında babasının hayratını da koruyup kollaması, bu külliyenin Osmanlı döneminde Adiliyye Zaviyesi adıyla anılmış olabileceğini göstermektedir.

\section{SONUÇ}

Hasankeyf denince, hafizalarda ve hatıralarda canlanan dört simgeden birisi, Şehabiye Medresesi veya yerleşmiş adıyla Sultan Süleyman Külliyesi'dir. Uzaklardan dikkati çeken minaresi, ören yeri içinde nispeten sağlam kalmış mimarisi ile heybetli görünüşü, "Hasankeyf Hatırası" için fotoğraf çekmek isteyenlerin özellikle seçtikleri bir konumda yer alıyordu. Külliyenin büyük bir bölümü "Şehabiye Medresesi" adıyla Eyyûbi hükümdarı Emir Şehabeddin Gazi tarafından yaptırılmıştır. Batıdaki eski medrese ise elden geçirilerek bu medreseye eklenmiştir. Şehabeddin Gazi’nin ilim öğrenme ve Allah'ın rızasına kavuşma aşkı ile yaptırdığı medrese, mescit ile birlikte kuşkusuz Artuklu geleneği içinde şekillendirilmiştir.

Medrese, bölgenin coğrafyası ve iklimine uygun olan bir mimari tasarımla, açık avlulu eyvanlı bir plan şeması üzerine yöreye özgü cas (alçı) harcı ve moloz taş ile inşa edilmiştir. Oğlu Sultan Süleyman, daha önce buradaki hücrelere defnedilen babası ve kardeşleri ile kendisi için iki türbe yaptırarak Hasankeyf Eyyûbi hanedanının varlığını ebedîleştirmek istemiş̧tir. Ayrıca minare, taçkapı ve çeşmenin yer aldığı doğu cephesi ile de babasının hatırasını yüceltip medreseyi anıtsal bir görünüme kavuşturmuştur.

130 yıl başkentliğini yaptığı Artuklu'nun sessiz sedasız yok oluşuna karşılık, uzun yıllar ayakta kalmayı başaran Eyyûbiler dönemi Hasankeyf'inin de sonu gelmiş, Şehabiye Medresesi'nin mihrapları ve geçiş mekânı olan kapalı avlunun kubbesi ile Sultan Süleyman'ın eklediği mimari unsurlar Ilısu Barajı kapsamında oluşturulan Yeni Hasankeyf'teki Kültür Park'a taşınmıştır. Diğer kısımları ise tüm Hasankeyf'le birlikte sular altında kalmıştır. Şehabiye Medresesi, Hasankeyf'ten günümüze ulaşabilen yapılar arasında tarihi ve kimliği bilinen, Eyyûbiler döneminin ve tüm Hasankeyf'in sembolü durumundaki anttlardan birisi olarak hatıralarda yerini koruyacaktır.

\section{KAYNAKÇA}

Bakırer, Ömür. Onü̧ ve Ondördüncü Yüzyıllarda Anadolu Mihrablarl, Ankara: Türk Tarih Kurumu, 1976.

Balüken, Yusuf. Târîhu Hısn-ı Keyfâ, Tahkîk ve'd Dirâse, Te'lif: El Hasan bin İbrahîm el-Münşî el-Hısnî, Arabca. İstanbul: Nûbihar Pak Ajans Yayıncılık, 1. Basım, 2019.

Bell, Gertrude. Erişim 7 Temmuz 2020. www.gerty.ncl.ac.uk

Darkot, Besim. "Hısn Keyfa”, İslam Ansiklopedisi. 5/453. İstanbul: MEB Yayınlarl, 1977.

Gabriel, Albert. Voyages Archéologique dans la Turquie Orientale. Paris: E. de Boccard, 1940.

Kılc1, Ali. "Hasankeyf Vakıf Eserleri”. V. Vakıf Haftası (Restorasyon ve Vakıfların Ekonomik ve Sosyal Etkileri Semineri), Ankara: VGM Yayınları, 1987, 159-192.

Miynat, Ali. Bir Ortaçağ Kenti: Hasankeyf. Muğla: Muğla Üniversitesi Sosyal Bilimler Enstitüsü, Yüksek Lisan Tezi, 2008.

Uluçam, Abdüsselam. Hasankeyf Projesi 2008-2009 Çalı̧̧maları. 2010.

Yurttaş, Hüseyin. "Hasankeyf'de Artuklu, Eyyûbi, Akkoyunlu ve Osmanlı Dönemi Mimari Eserleri”, Türkler, ed. Hasan Celal Güzel. 8/170-172. Ankara: Yeni Türkiye Yayınları, 2002.

Yurttaş, Hüseyin. Hasankeyf Yapılarının Sanat Tarihimizdeki Yeri. Erzurum: Atatürk Üniversitesi, Sosyal Bilimler Enstitüsü, Doktora Tezi, 1991.

Zengin, Burhan. Hasankeyf Tarihi ve Tarihi Eserleri. İstanbul: Prestij Reklam Ltd. Şti., 2. Basım, 2001.

998 Numaralı Muhâsebe-i Vilâyet-i Diyâr-i Bekr ve Arab ve Zü'l-Kâdiriyye Defteri (937/1530) 1/261-266, Ankara: 1998. 


\section{ÇIZIMLER}

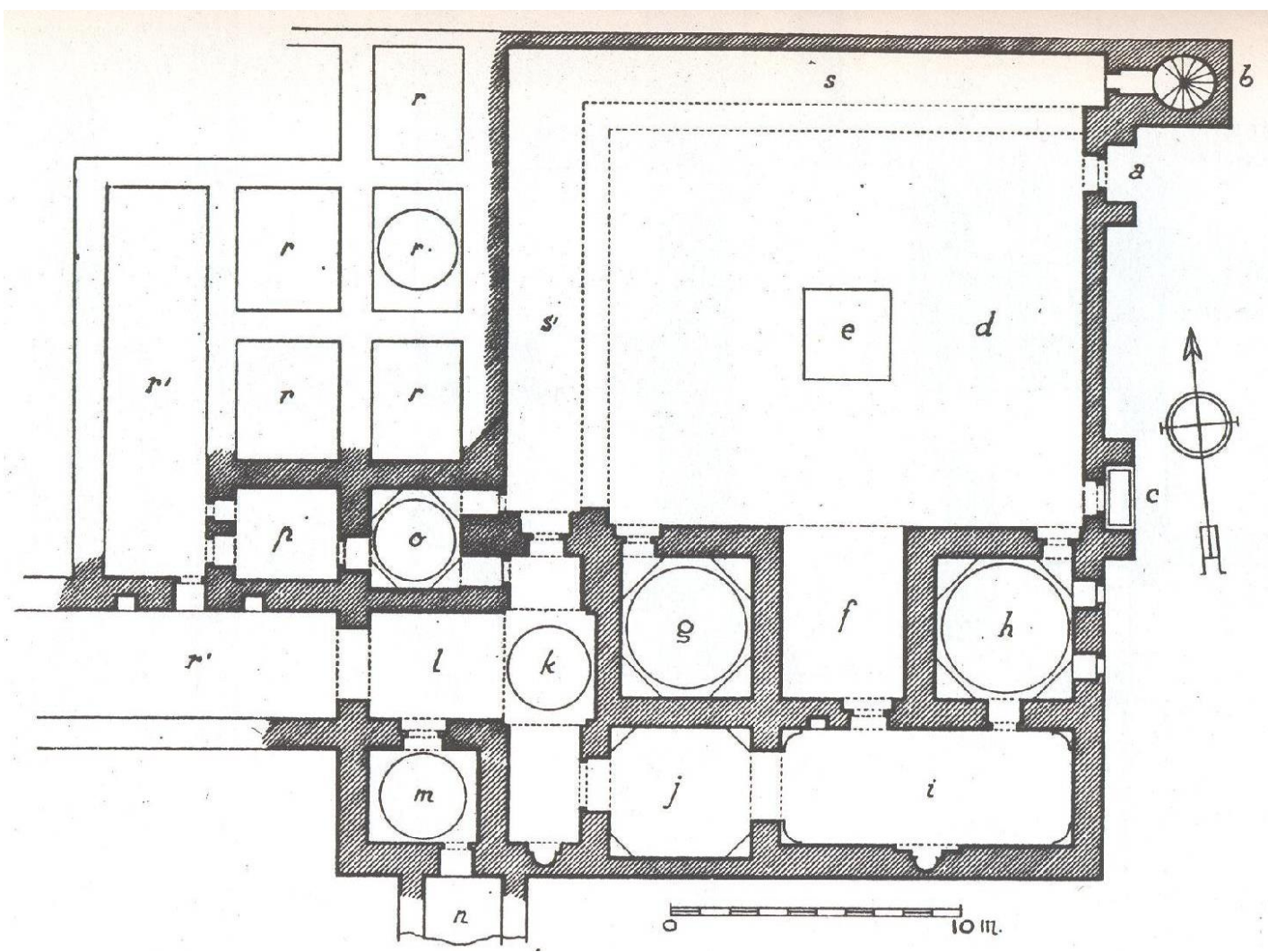

Çizim 1: Sultan Süleyman Külliyesi (Şehabiye Medresesi) (A. Gabriel'den).

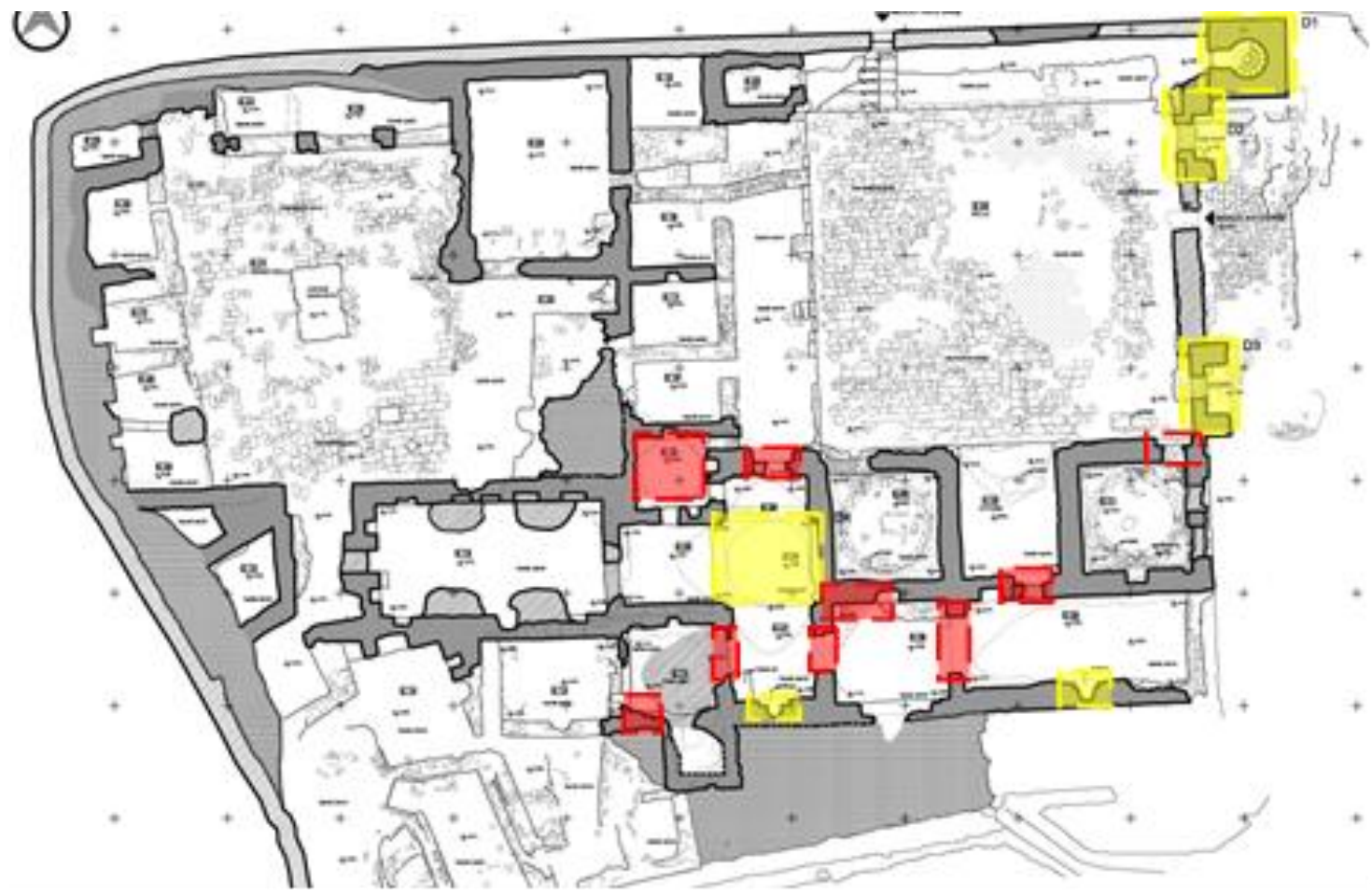

Çizim 2: Kazılar sonrasında Şehabiye Medresesi (Çizim: N. Demirtaş). 


\section{RESIMLER}

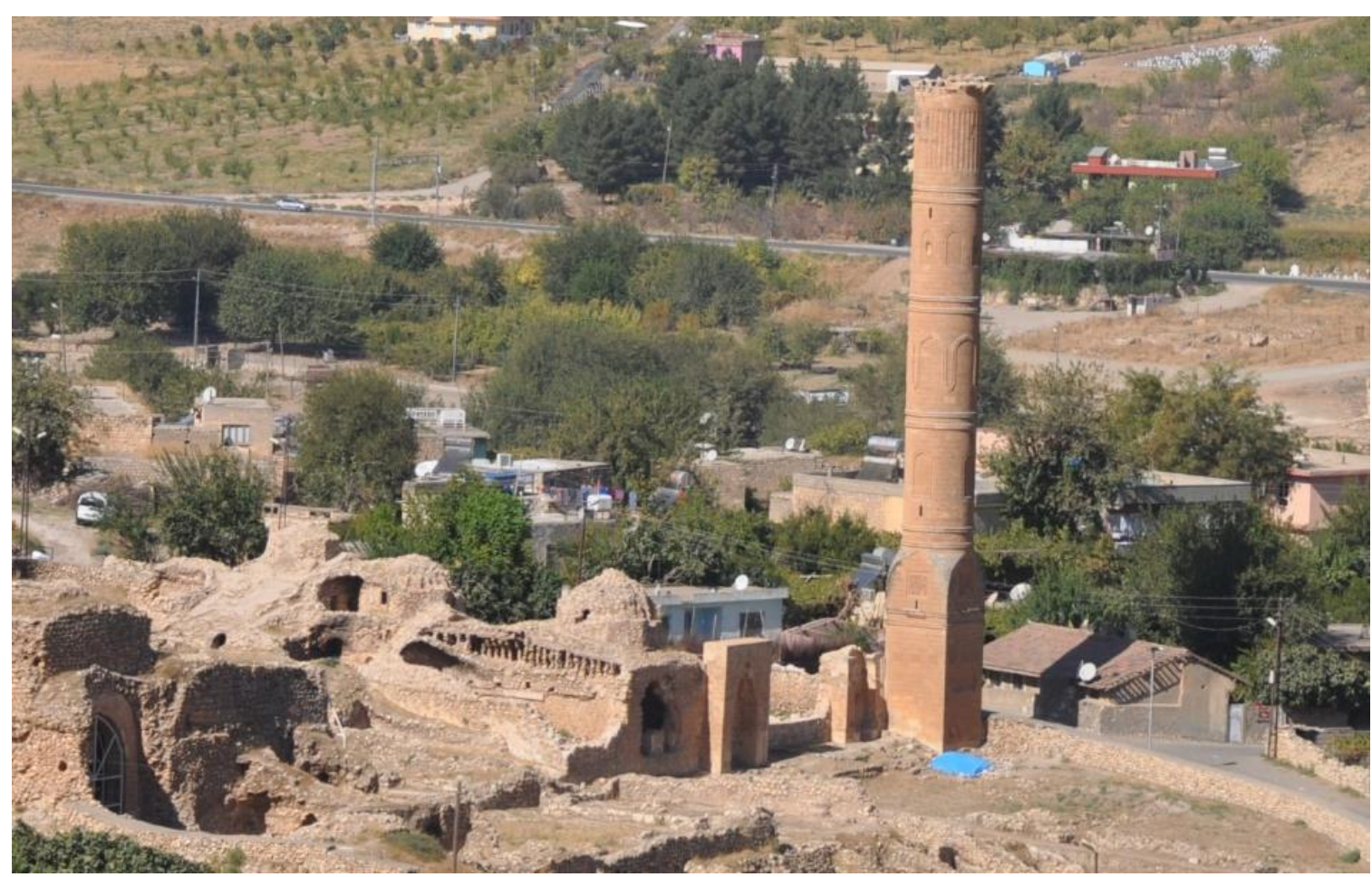

Resim 1: Şehabiye Medresesi’nin (S. Süleyman Camisi) Güneydoğudan Genel Görünüşü.

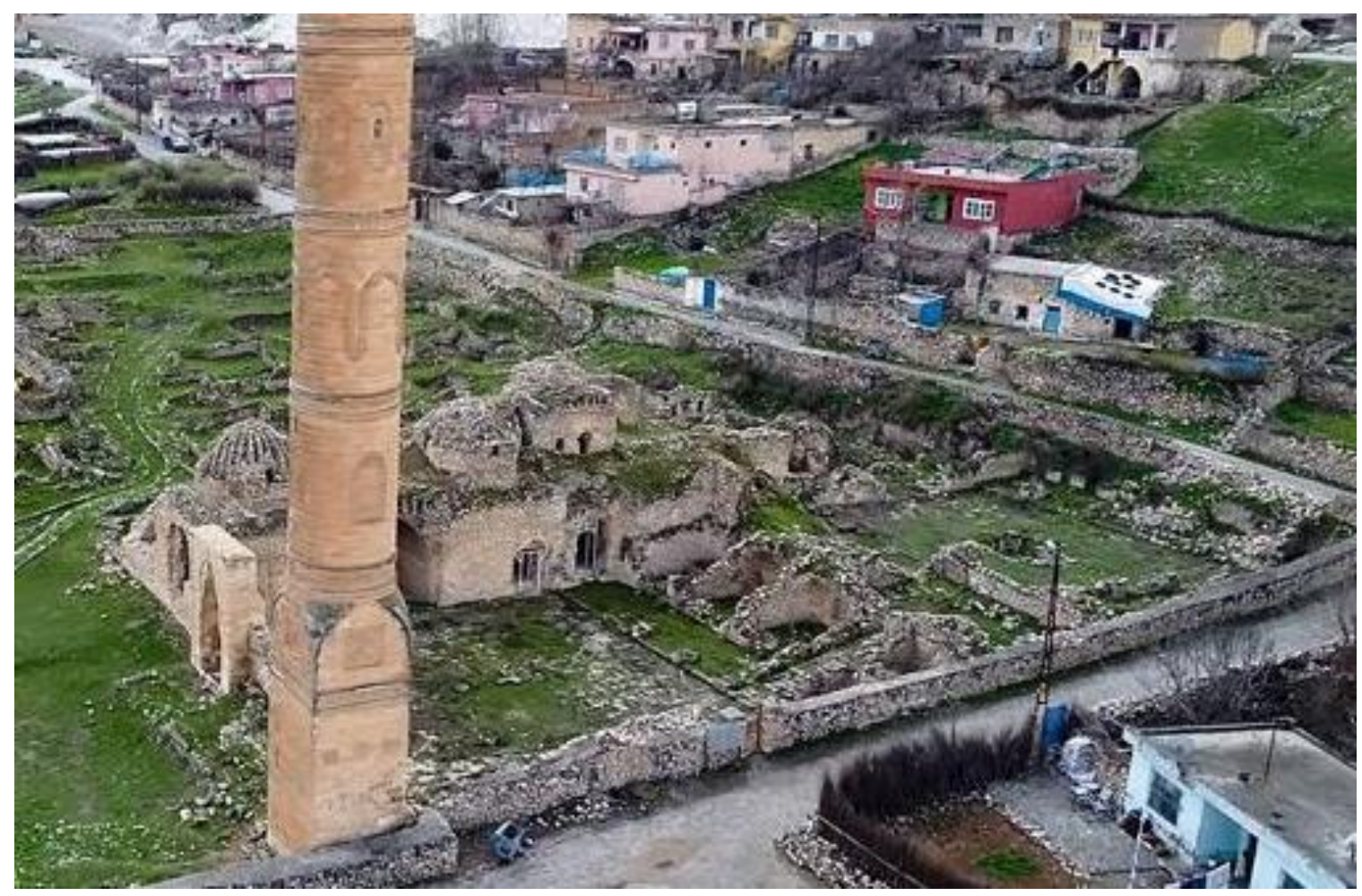

Resim 2: Şehabiye Medresesi’nin (S. Süleyman Camisi) Kuzeydoğudan Genel Görünüşü. 


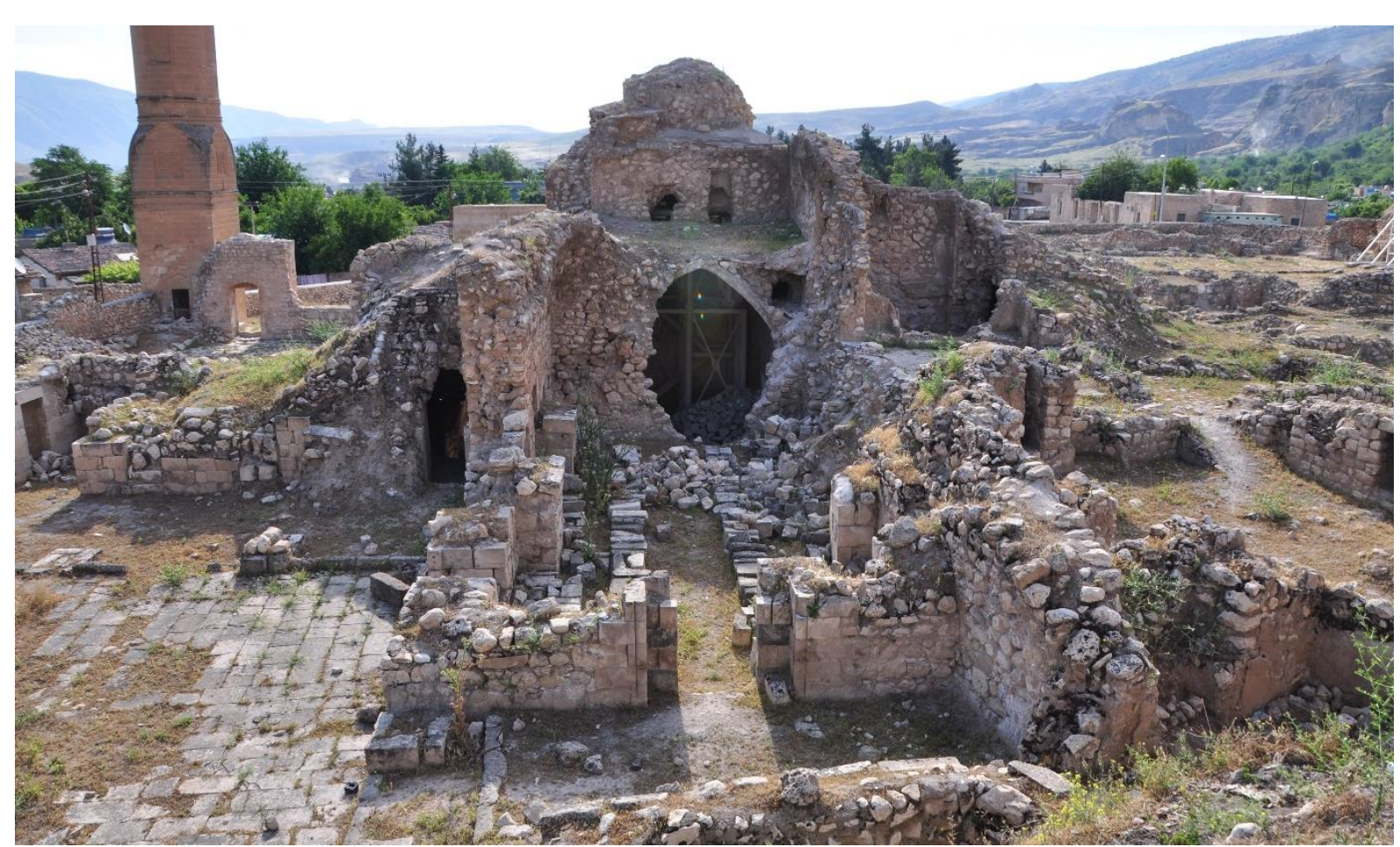

Resim 3: Külliyenin Batıdan (Artuklu Medresesi Tarafindan) Görünüşü.

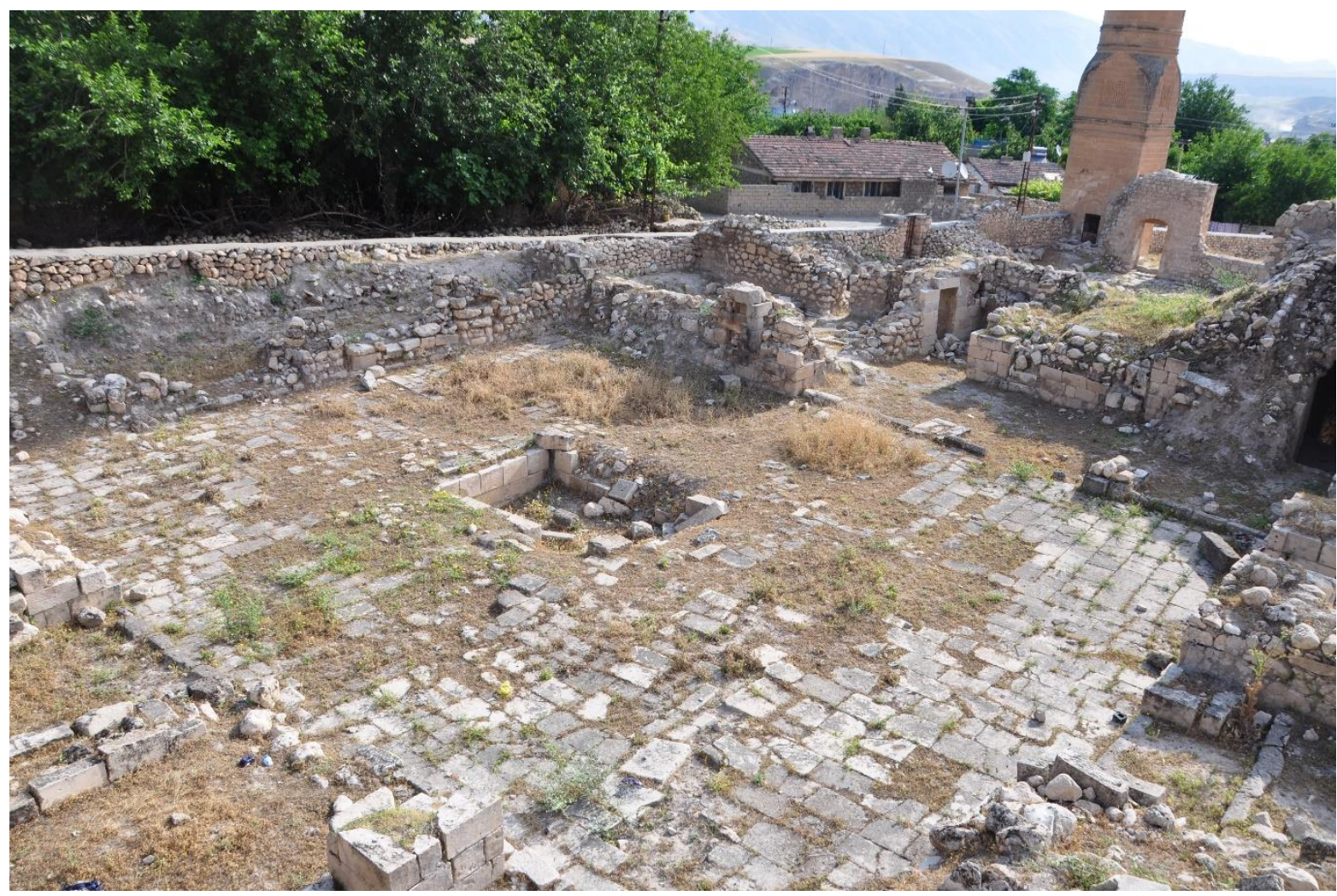

Resim 4: Eski (Artuklu) Medrese Kalıntılart. 


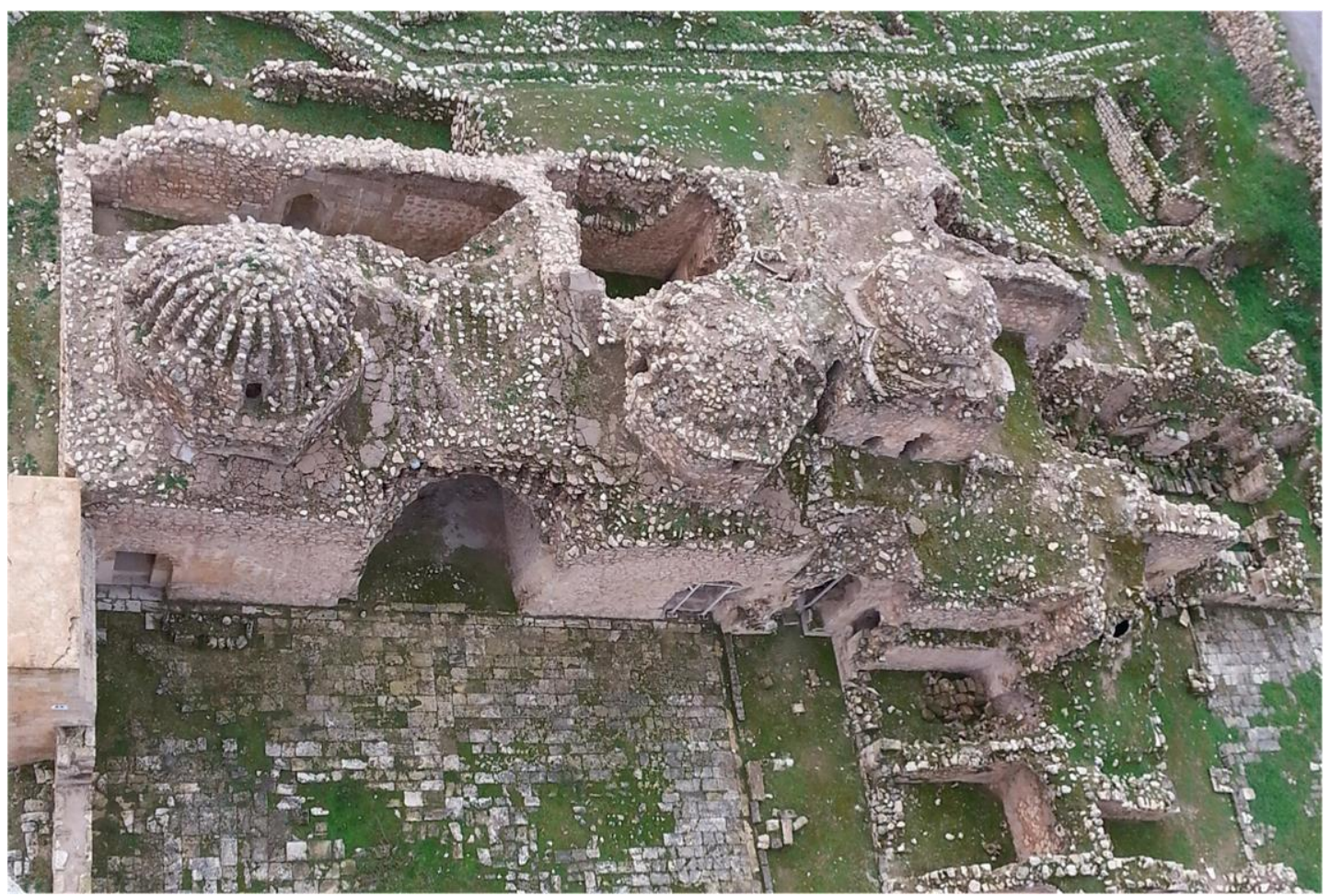

Resim 5: Şehabiye Medresesi’nin Minareden Görünüşü.

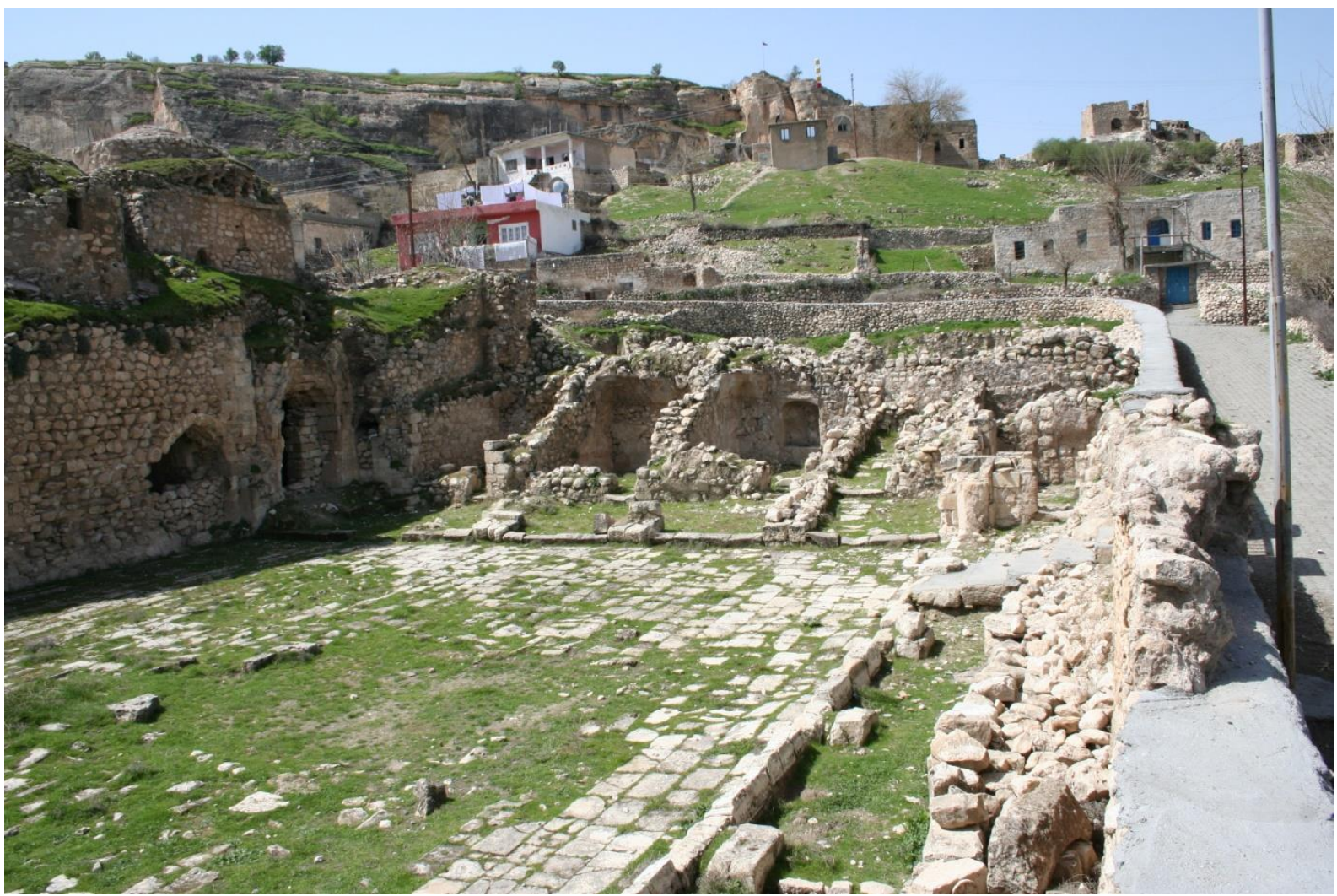

Resim 6: Medrese Avlusu ve Öğrenci Odaları Kalıntılart. 


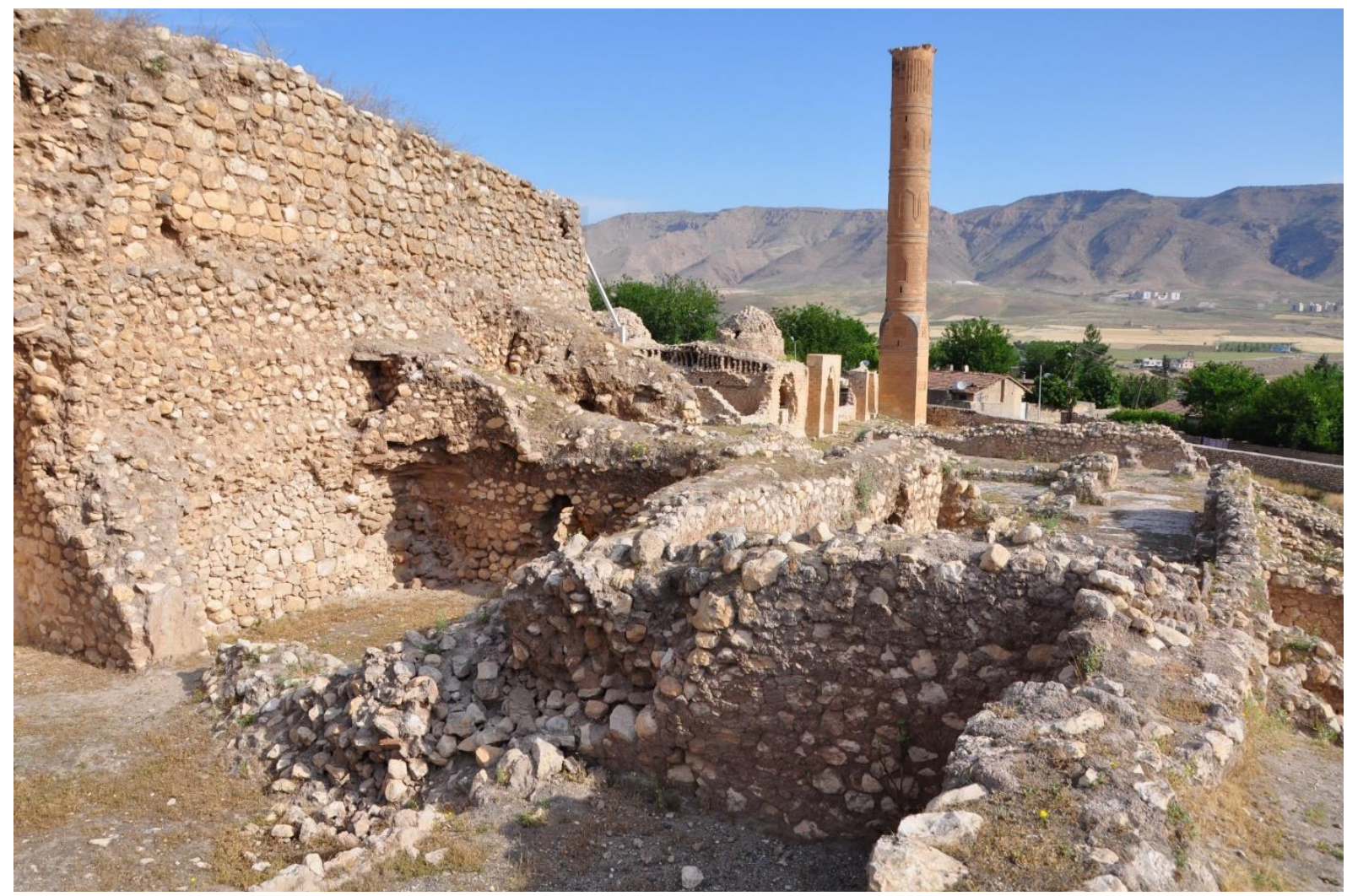

Resim 7: Medresenin Kazılarla Ortaya Çıkarılan Doğu Kanadı.

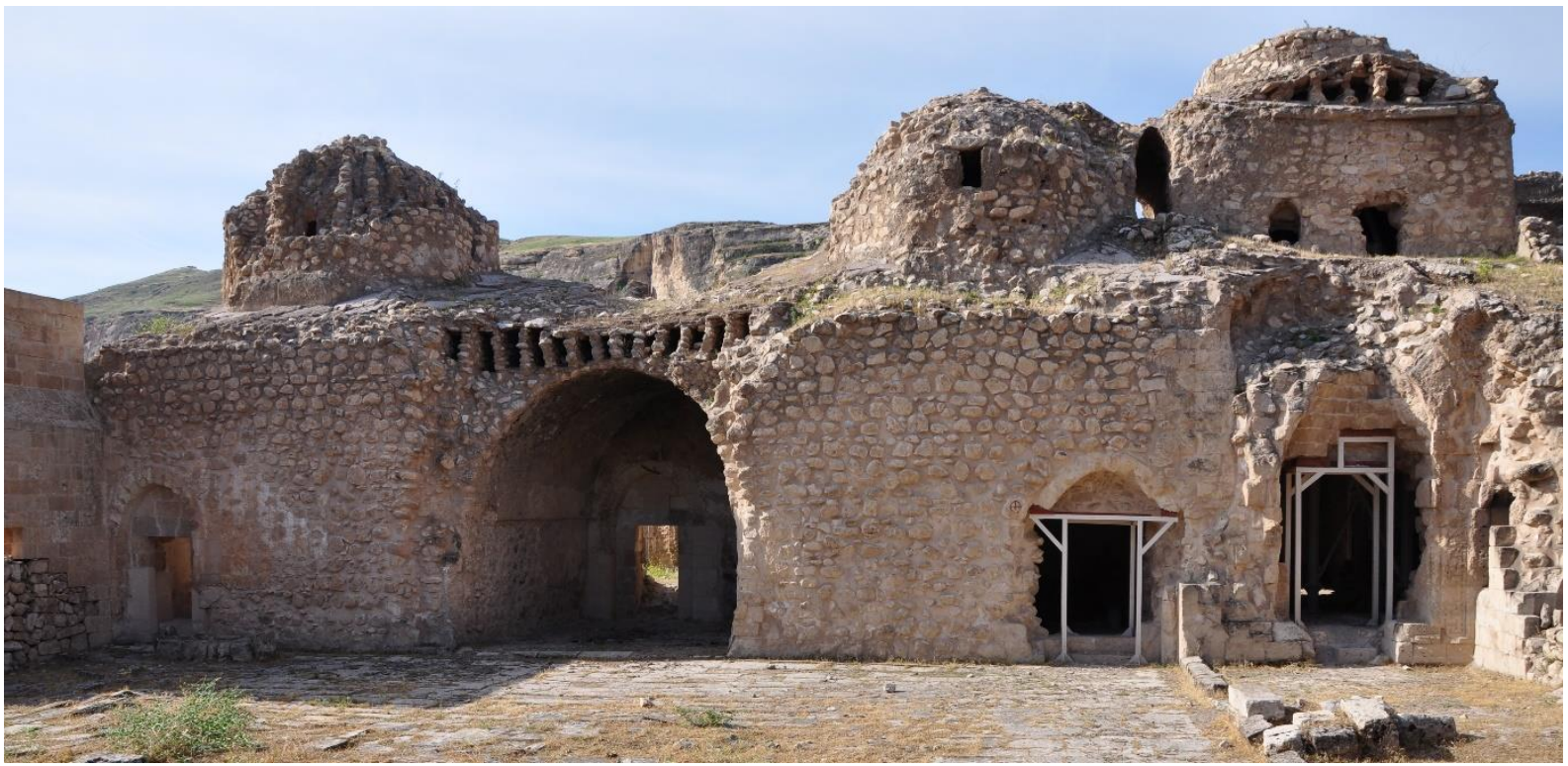

Resim 8: Medresenin Eyvanı ve Türbeye Dönüştürülen Müderris Odaları. 


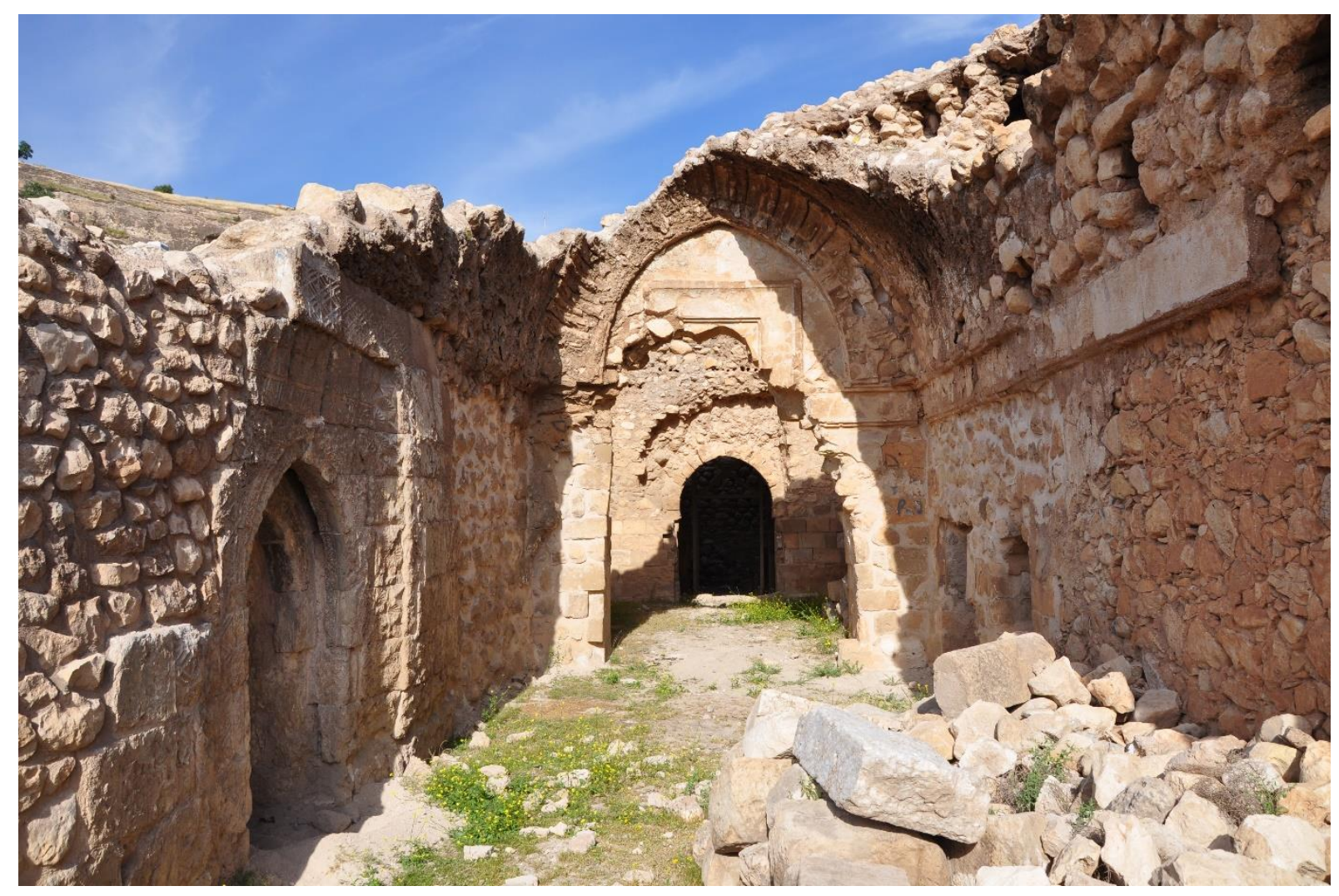

Resim 9: Mescidin (Harim) Orta Mekânı.

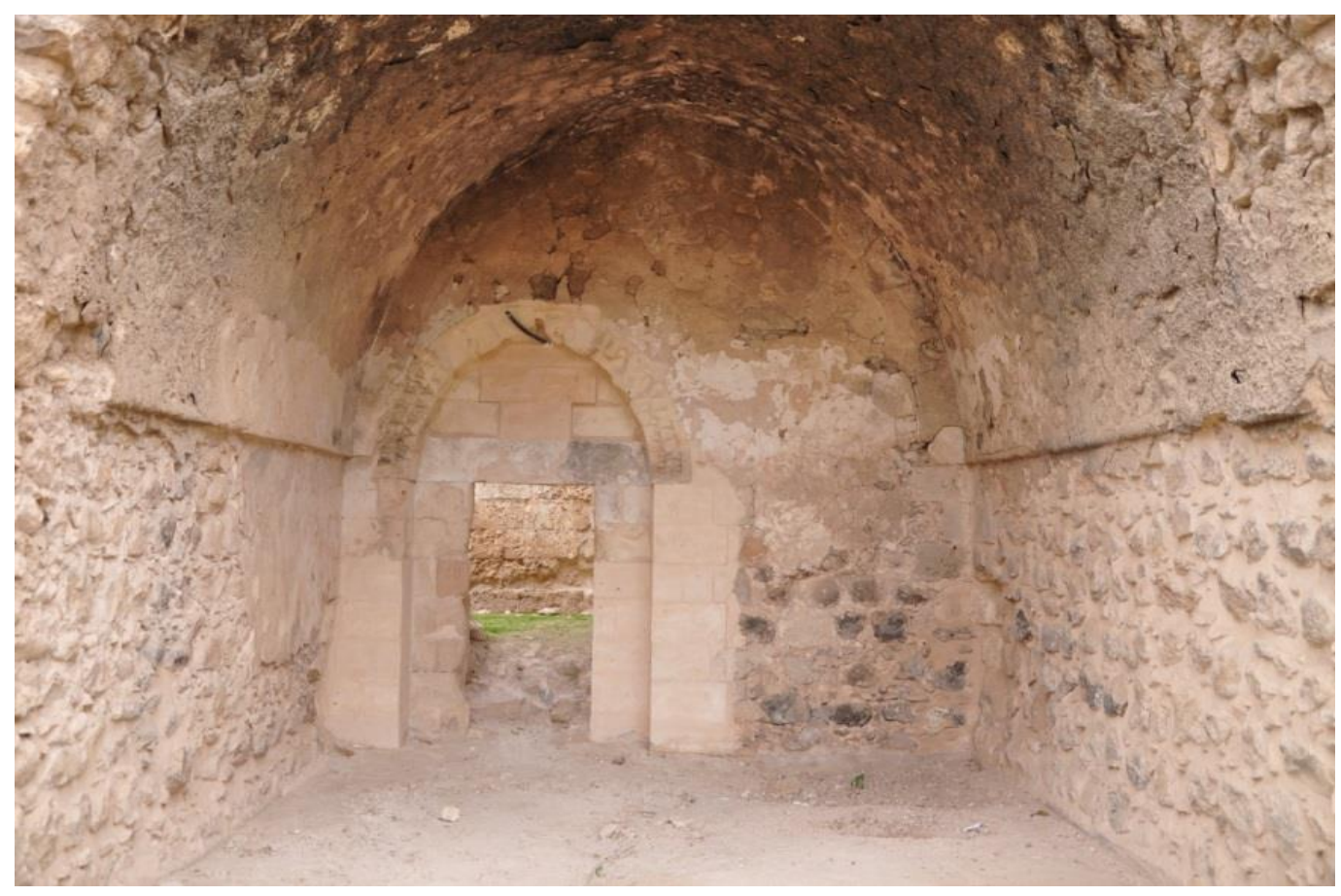

Resim 10: Mescidin Batı Bölümü. 


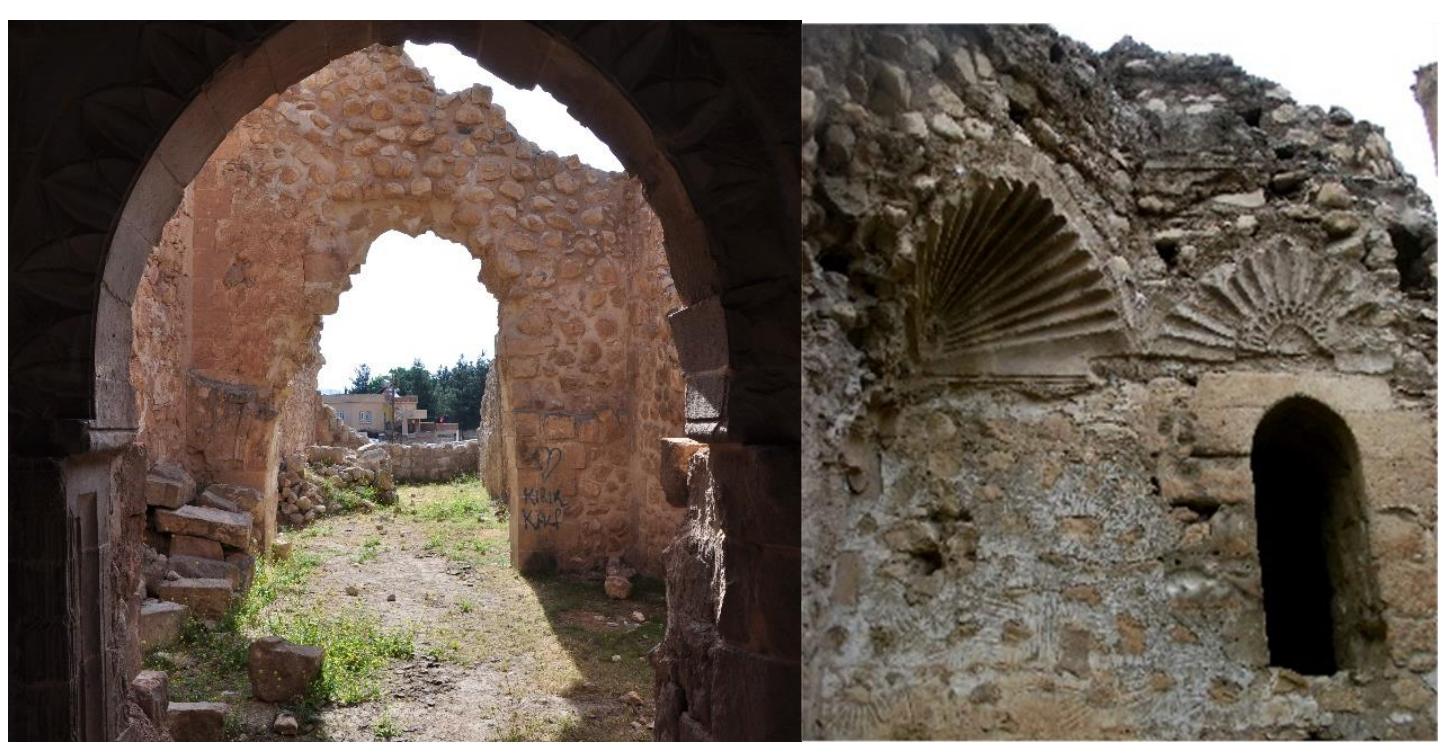

Resim 11: Mescitten Yan Mekânlara Geçilen Kemerler ve Örtü Geçişi Süslemeleri

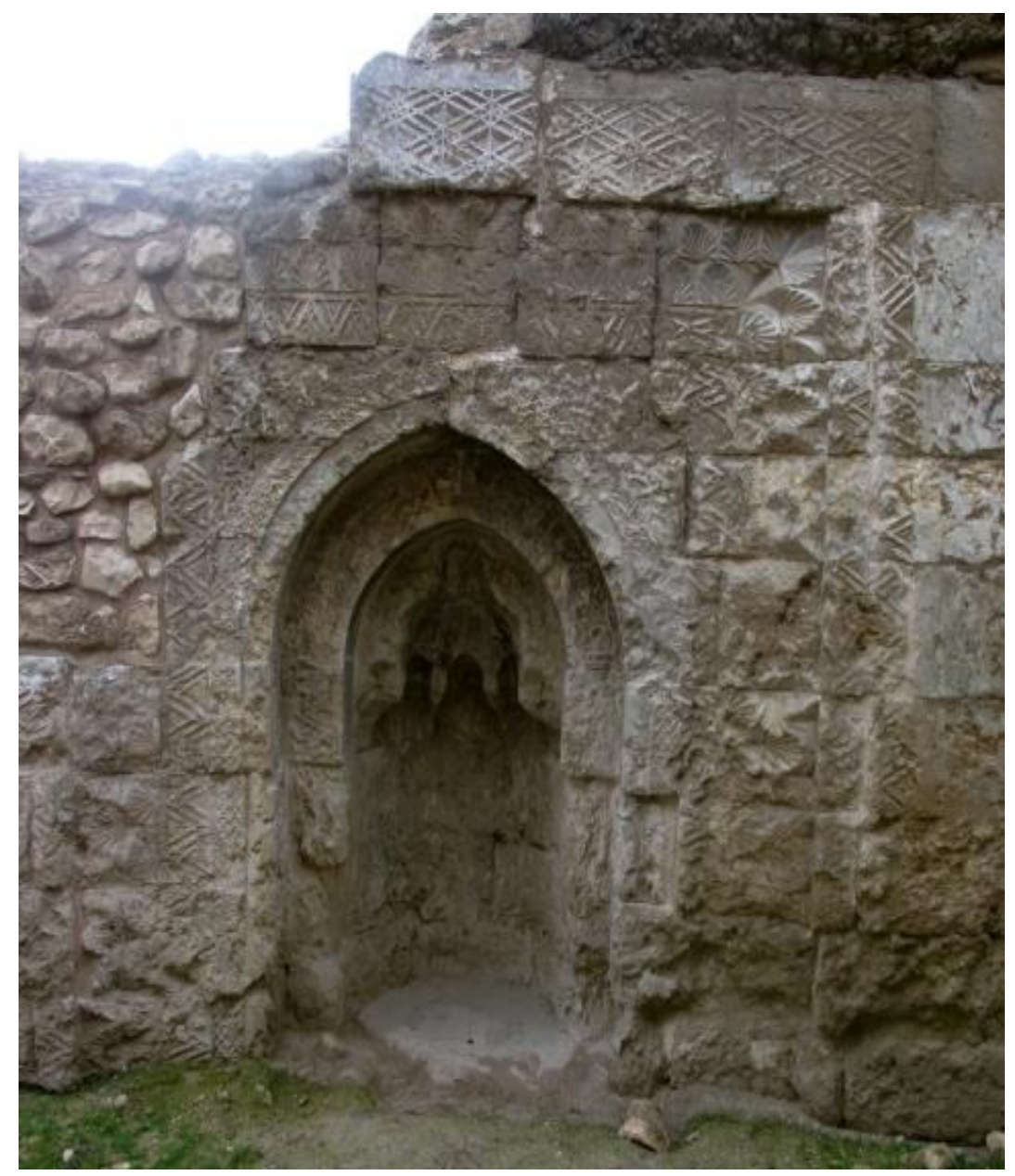

Resim 12: Mescidin Orta Mihrabı. 


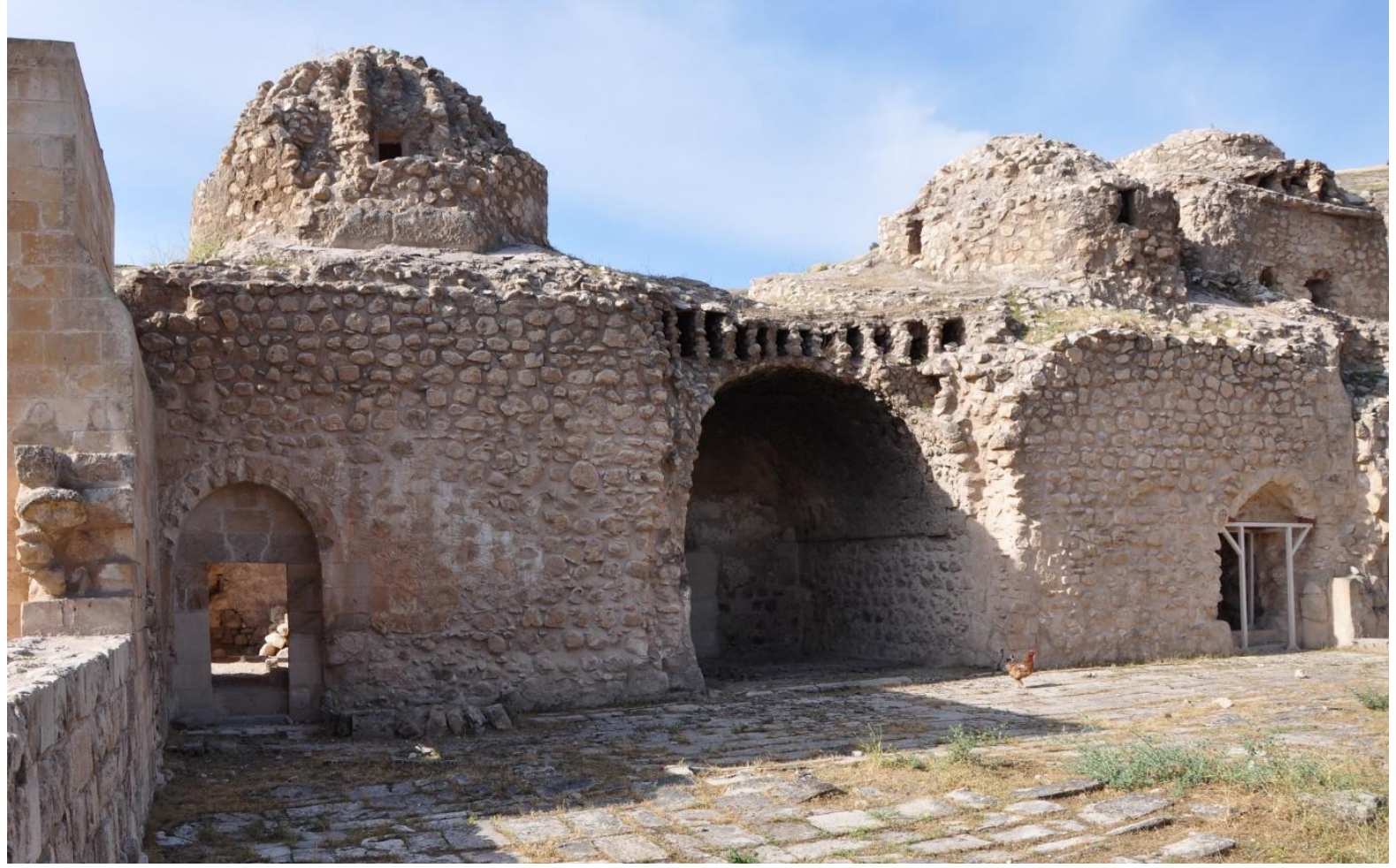

Resim 13: Şehabeddin Gazi (Să̆da) ve Sultan Süleyman (Solda) Türbeleri.

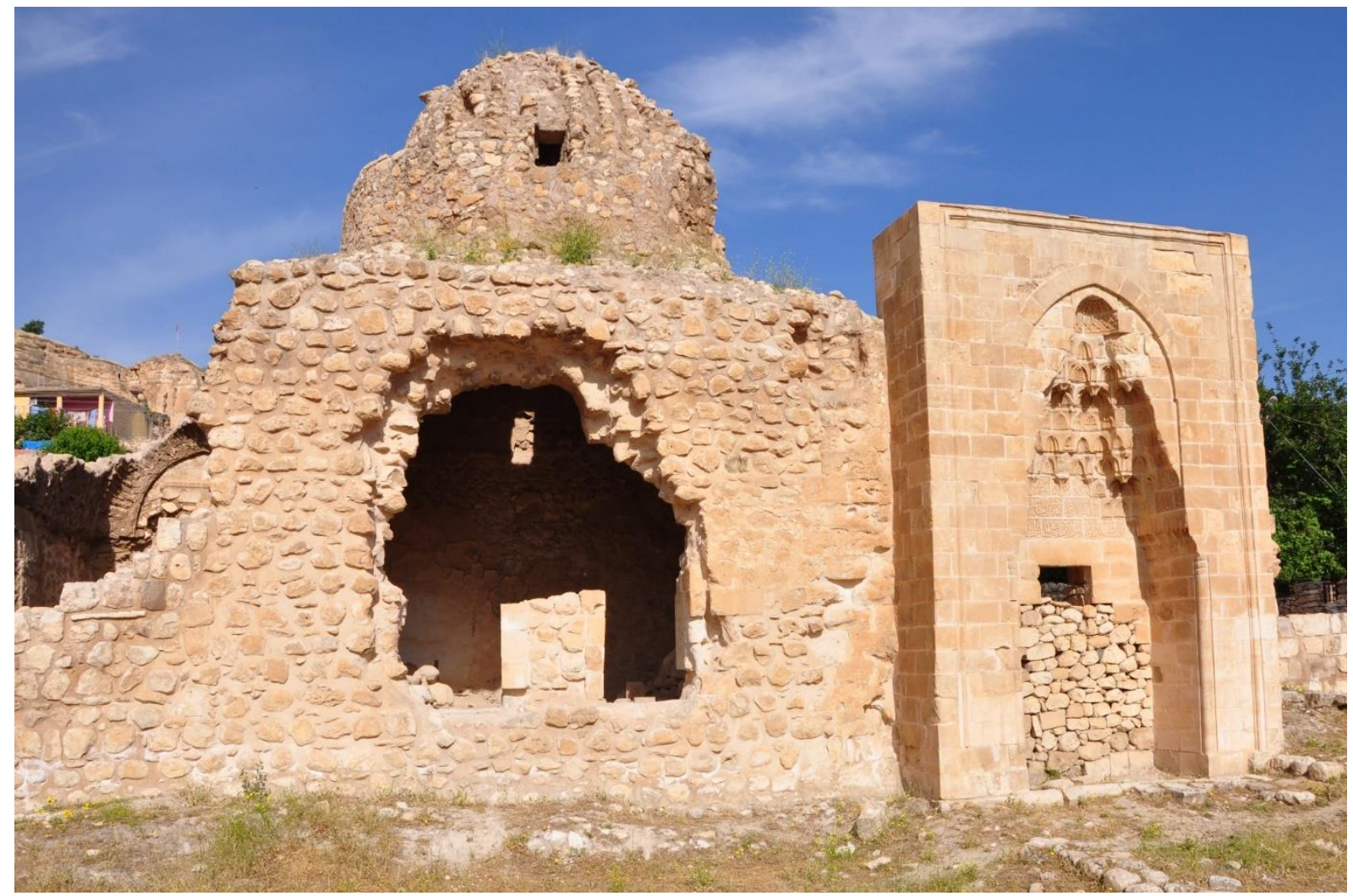

Resim 14: Sultan Süleyman Türbesi (Doğudan Görünüşü) ve Kastal (Çeşme). 


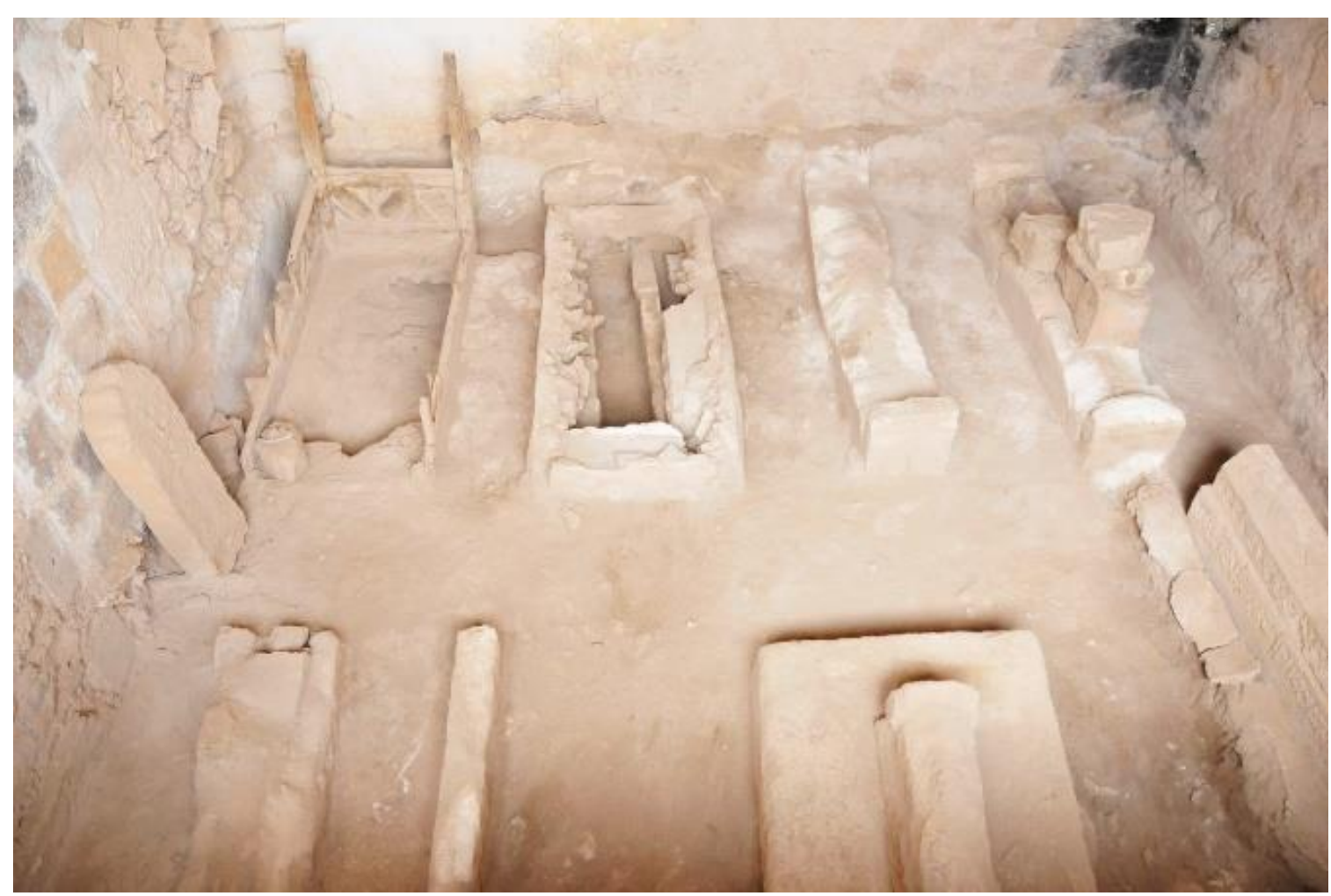

Resim 15: Sultan Süleyman Türbesi İçindeki Mezar ve Sanduka Kalıntıları.

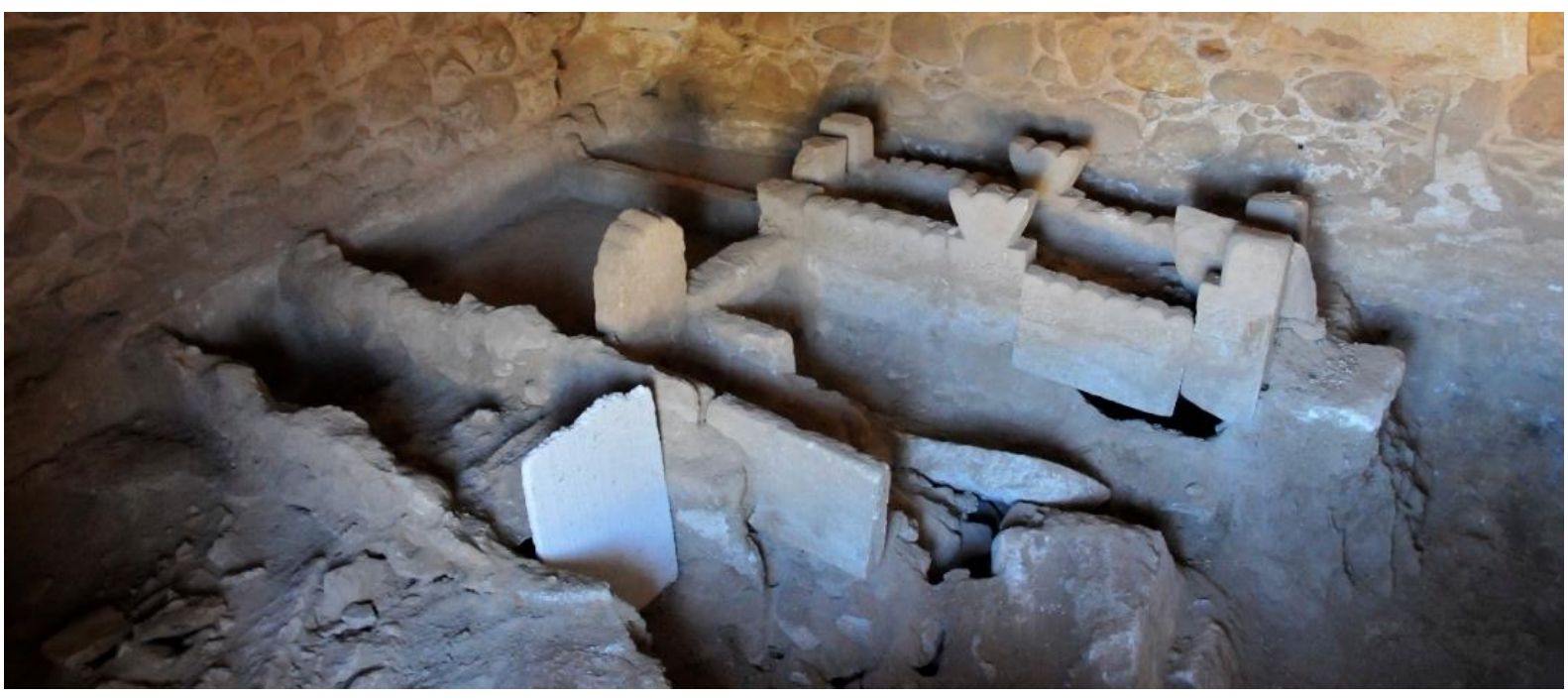

Resim 16: Şehabeddin Gazi Türbesi İçindeki Mezar ve Sanduka Kalıntıları. 


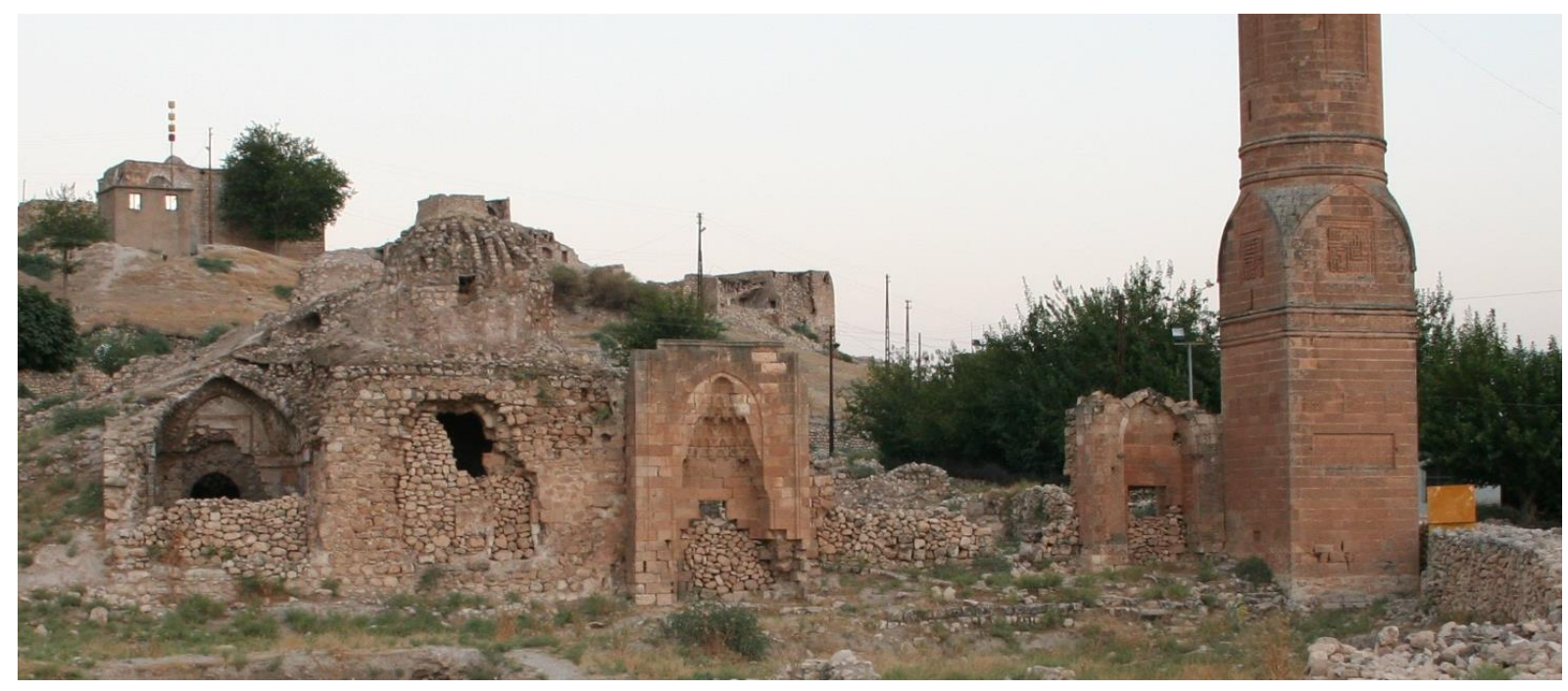

Resim 17: Şehabiye Medresesi 'nin Doğu Cephesi.

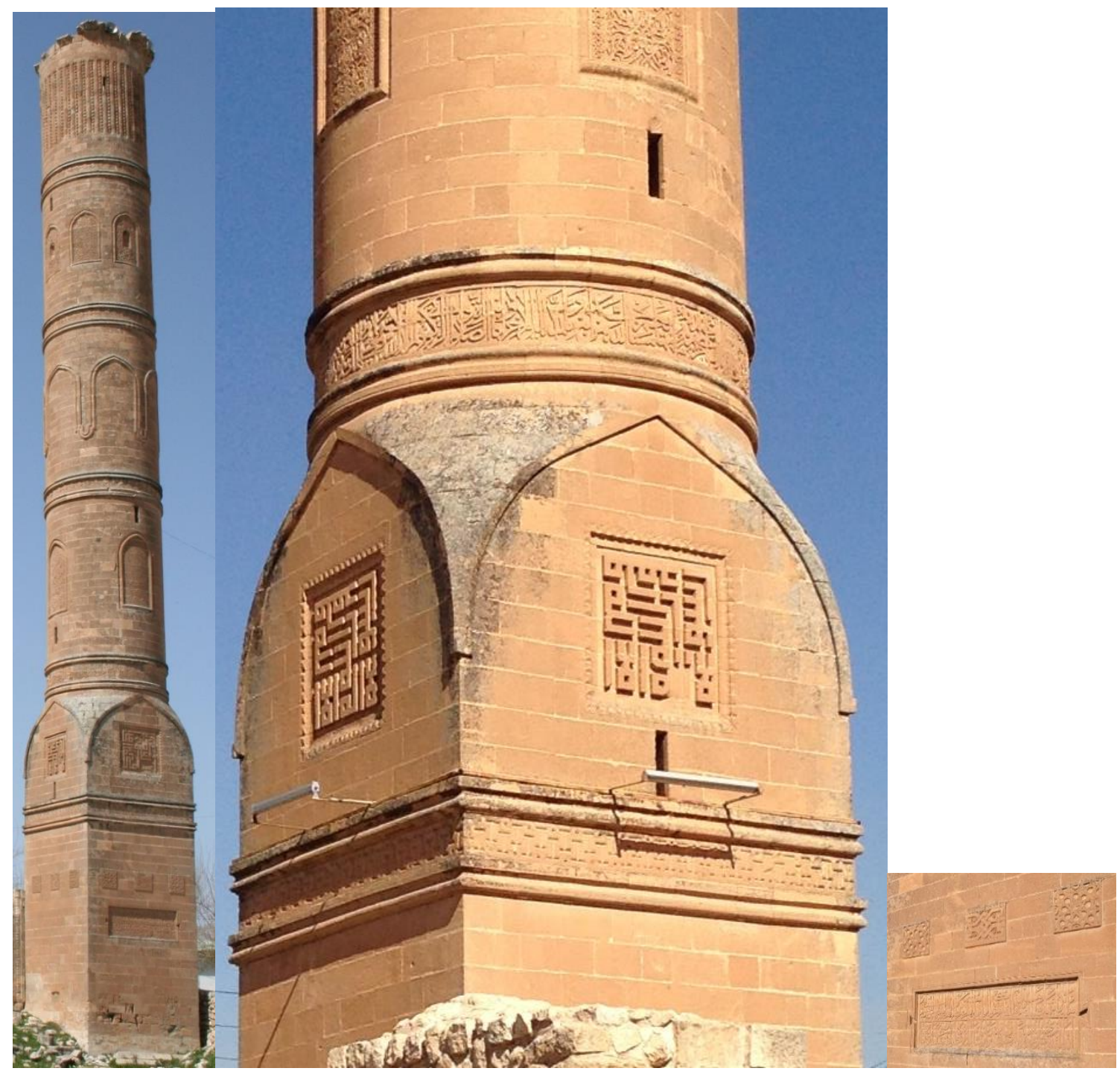

Resim 18: Minare ve Süsleme Detaylart. 


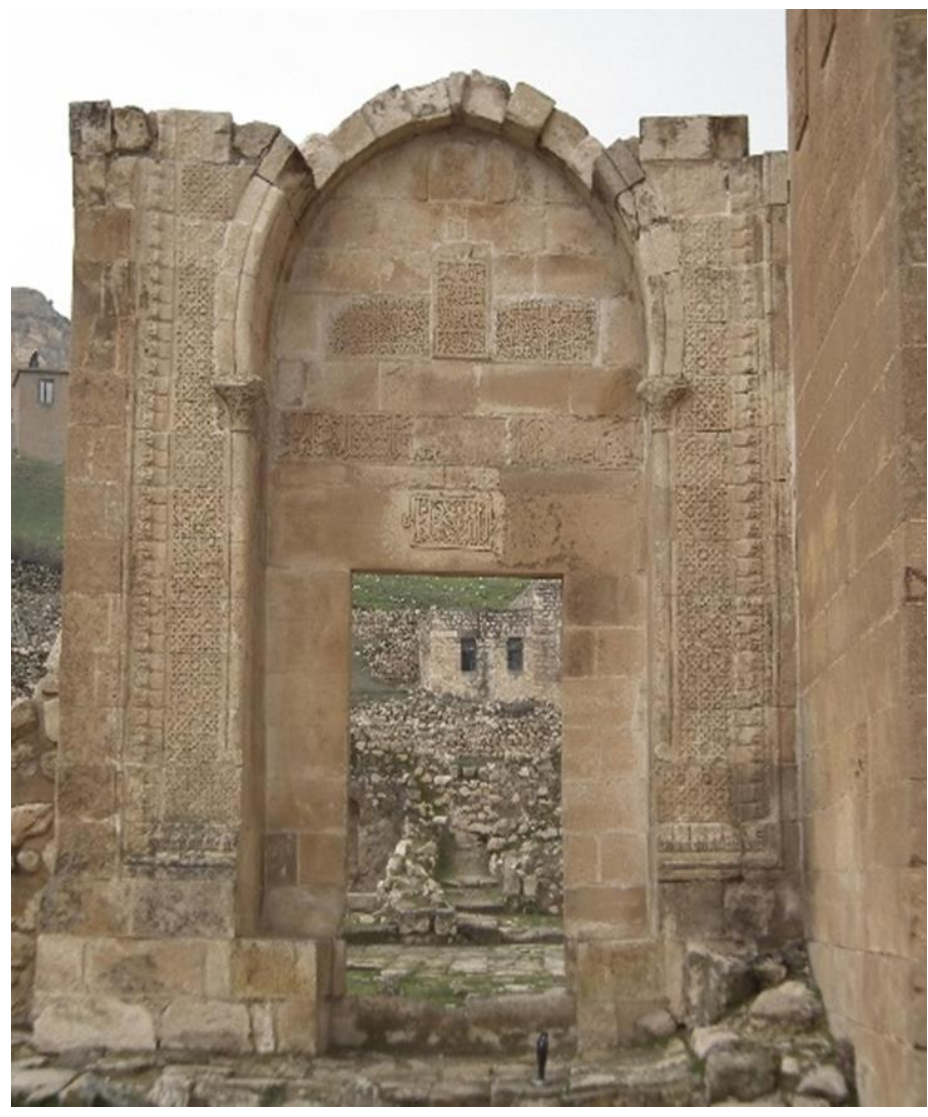

Resim 19: Taçkapı

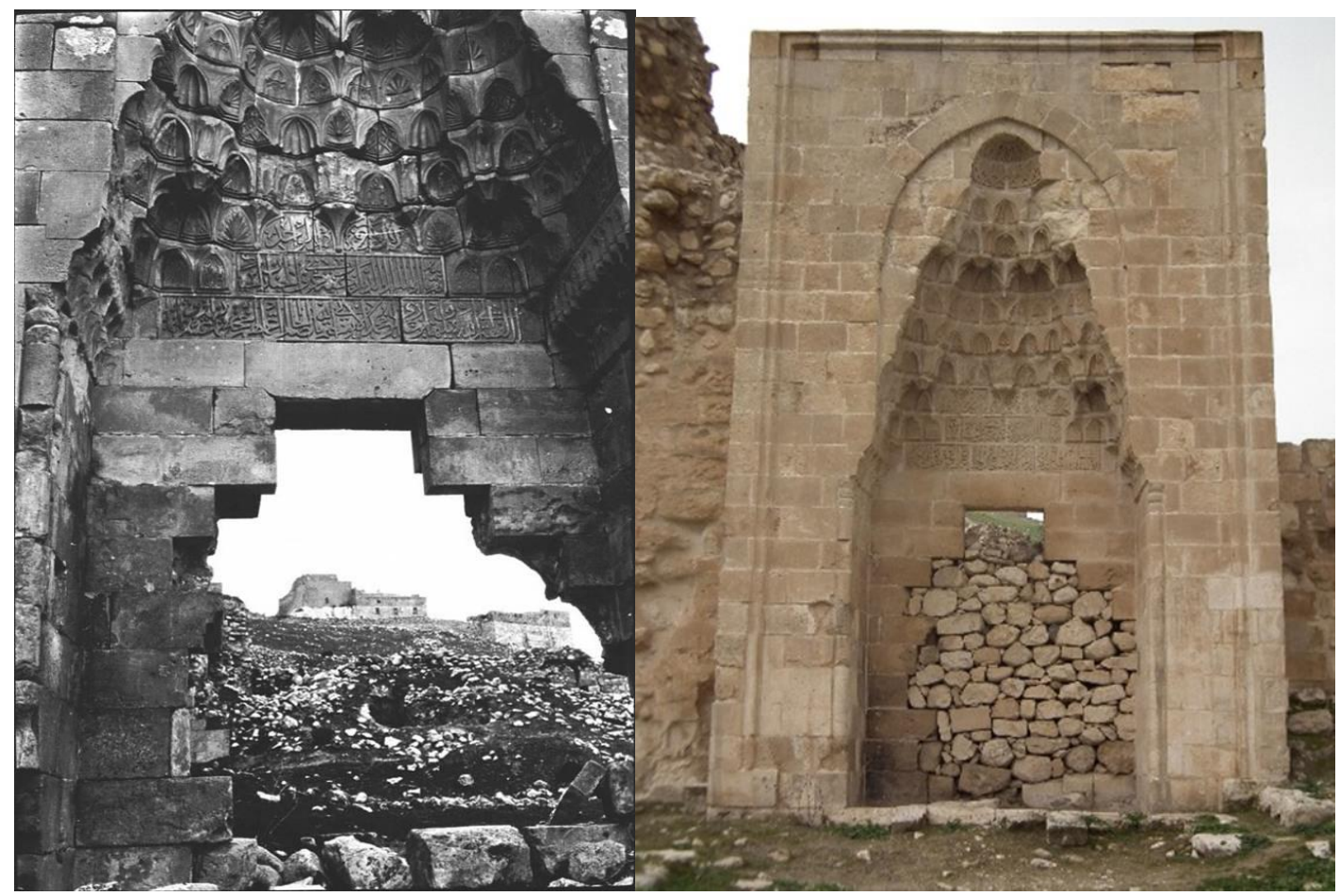

Resim 20: Çeşmenin Eski Hali (G. Bell) Resim 21: Çeşmenin Taşınma Sırasındaki Durumu 


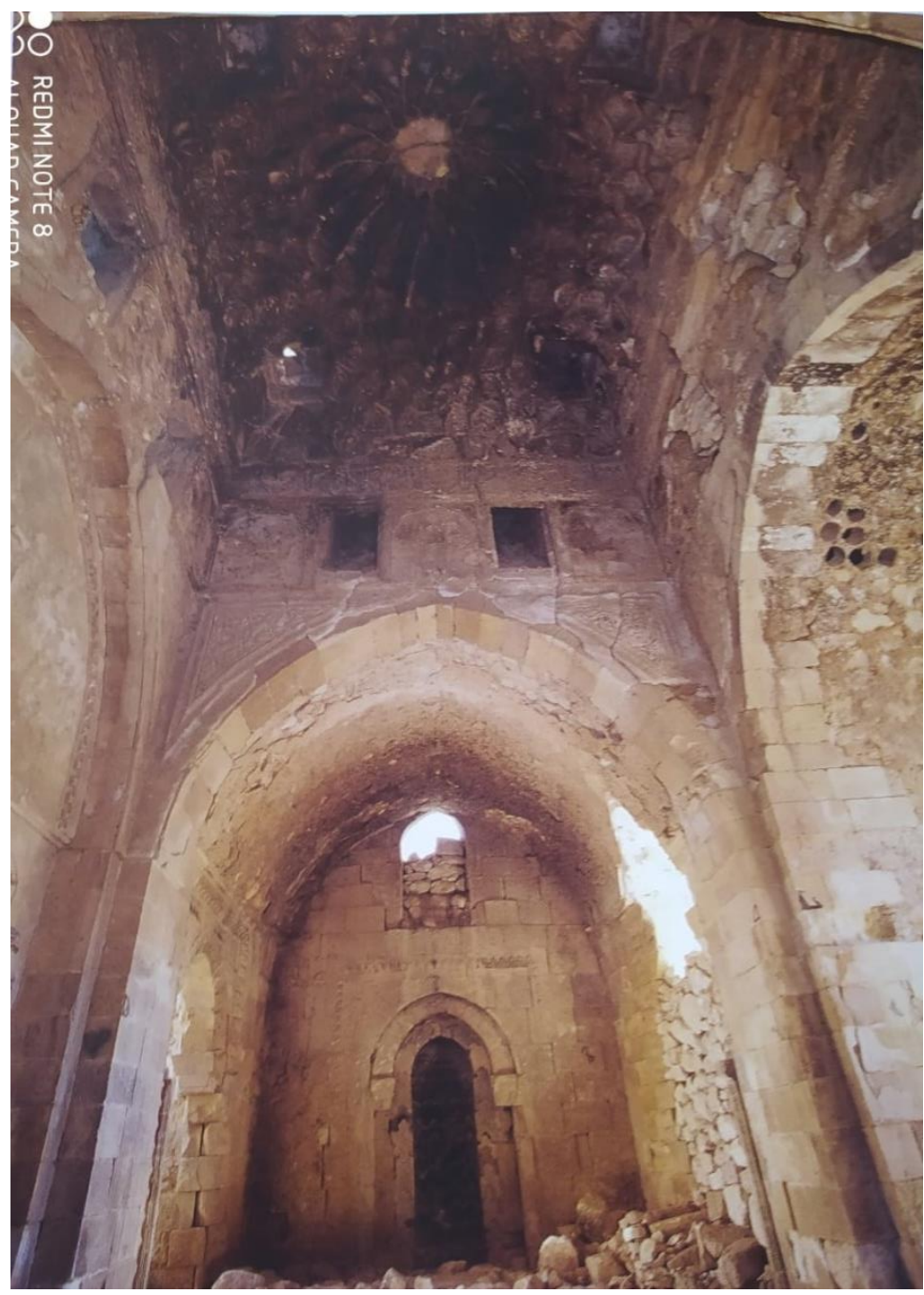

Resim 22: Kapalı avlu kubbesi ve Güney Eyvanı. (A. Gabriel).

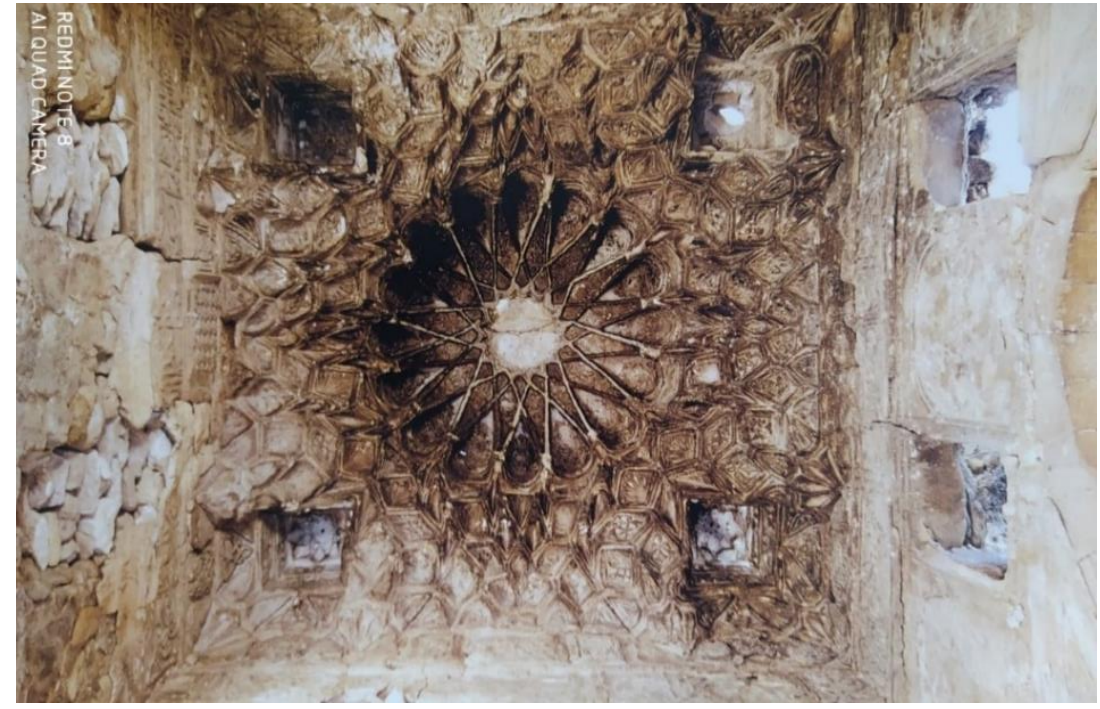

Resim 23: Kapalı Avlunun Kubbesi, İçten Görünüş. (A. Gabriel). 


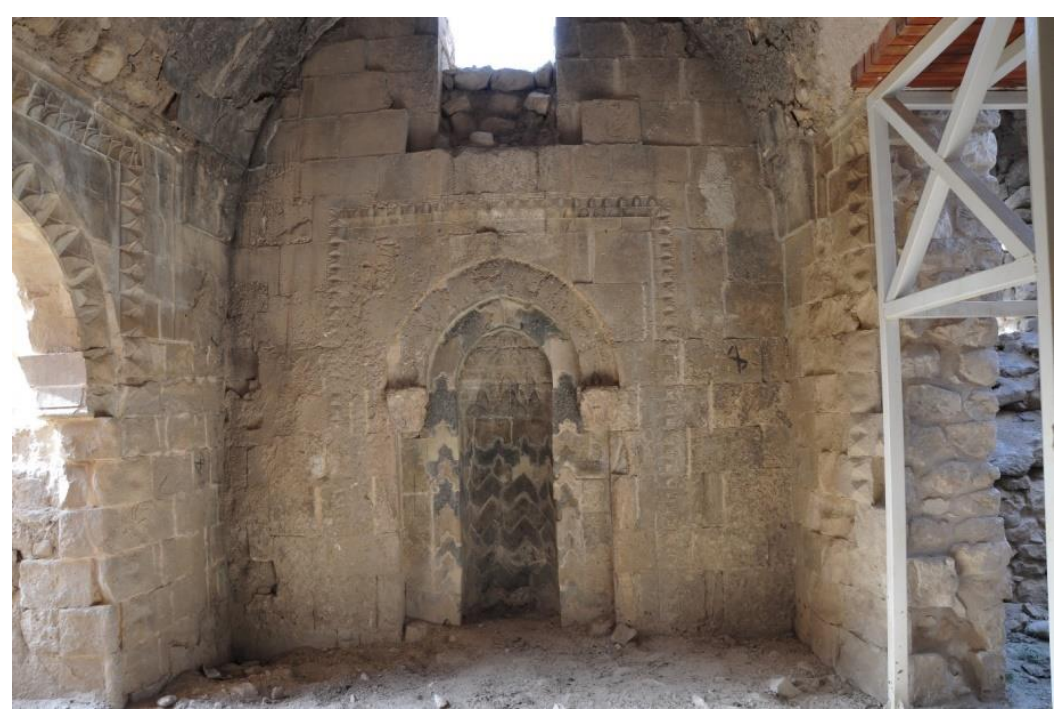

Resim 24: Kapalı Avlunun Güney Eyvanı ve Mihrabı.

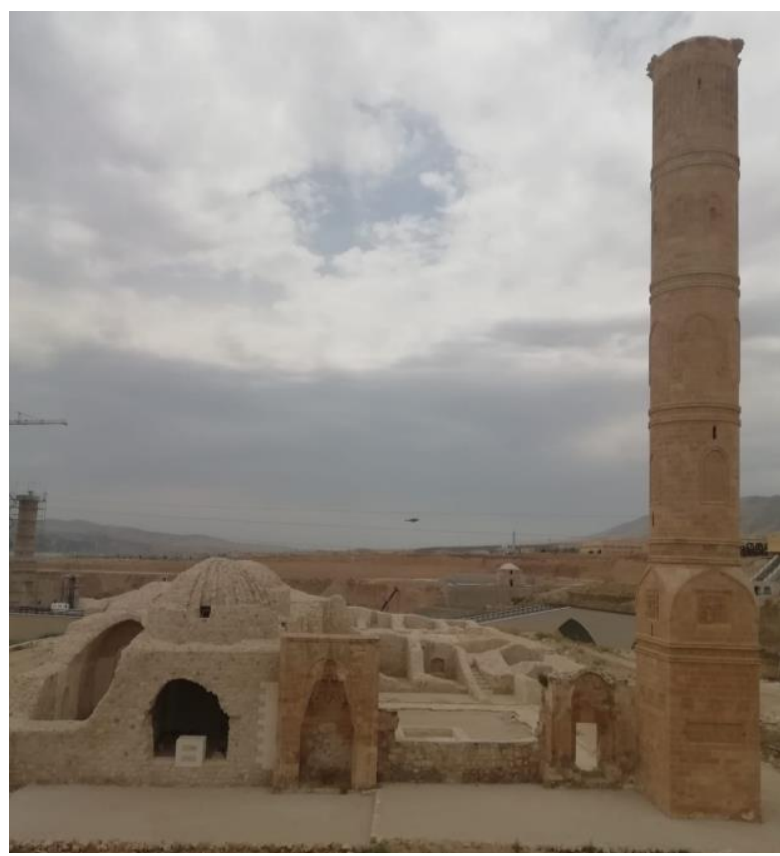

Resim 25: Yeni Hasankeyf Kültür Park’ta Şehabiye Medresesi 1.

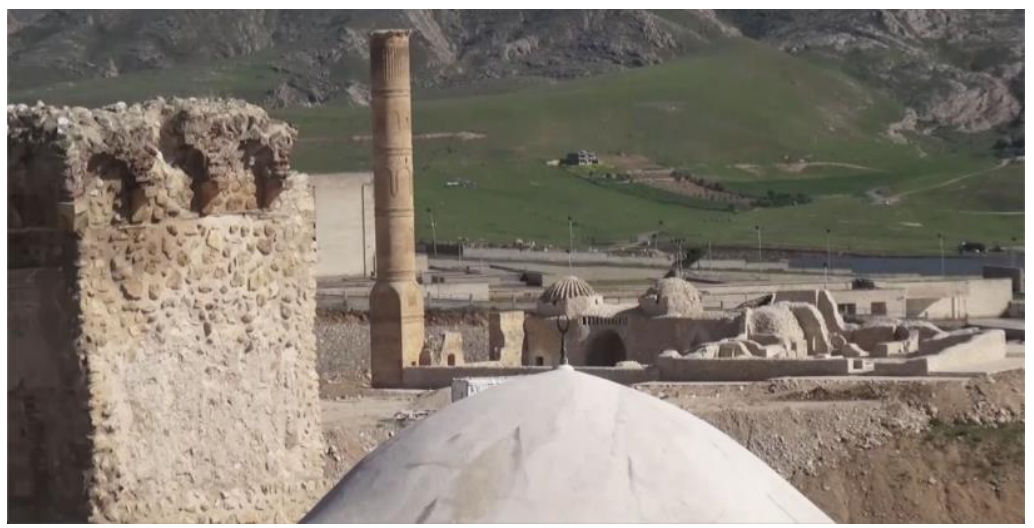

Resim 26: Yeni Hasankeyf Kültür Park'ta Şehabiye Medresesi 2. 